\title{
Investigation of large transit vehicle accidents and establishing appropriate protection for wheelchair riders
}

\author{
Greg Shaw, PhD \\ Department of Mechanical and Aerospace Engineering, Center for Applied Biomechanics, University of Virginia, \\ Charlottesville, VA
}

\begin{abstract}
Securing wheelchairs and restraining wheelchair riders on buses is difficult for many wheelchair riders and transit providers. This study examined injury-producing events aboard large transit buses in general in an attempt to better understand the potential risks and required protection for wheelchair users. The study found that few injuries and fatalities occur on large transit buses. Examination of the relatively few injury-producing events advanced the understanding of these events in terms of acceleration/deceleration magnitude and direction. Low acceleration/deceleration, or low- $g$, events such as those involving abrupt braking or turning occur frequently and are associated with approximately half of onboard passenger injuries. Unfortunately, the actual frequency of high- $g$ events was not determined. Most of the injurious events involved the bus rapidly decelerating because of frontal impacts with another vehicle or roadside object. Further study is needed to determine the magnitude and frequency of high- $g$ events. This information is necessary to determine the level of protection commensurate with real-world risk necessary for wheelchair riders in the transit bus environment and may ultimately facilitate the development of easier-to-use safety systems that secure and restrain wheelchairs and their riders.
\end{abstract}

Key words: bus damage, crash protection, crash tests, database, fatality rate, peak acceleration, risk, transit bus, transport safety, wheelchair riders.

\section{INTRODUCTION}

Wheelchairs users who ride buses should be afforded a level of safety comparable to that enjoyed by other pas- sengers [1]. National and international efforts to improve wheelchair rider safety have produced safety standards for the hardware used to secure the wheelchair and the occupant (wheelchair tie-down and occupant restraint systems [WTORS]) [2]. These efforts have focused on high- $g$ frontal impacts that are more likely for smaller vehicles, such as passenger vans, and have facilitated the production of the crash-tested WTORS that are currently in widespread use. Most systems employ four straps to secure the wheelchair and a lap and shoulder belt to restrain the occupant.

Offering safe travel for wheelchair riders is one of the most challenging tasks facing providers of large transit city buses [3]. Existing crash-tested strap WTORS that

Abbreviations: $\mathrm{ADA}=$ Americans with Disabilities Act, $\mathrm{DOT}=$ Department of Transportation, FARS = Fatality Analysis Reporting System, GES = General Estimates System, MOT = Ministry of Transportation, NSC = National Safety Council, NTSB $=$ National Transportation Safety Board, NYSDOT = New York State DOT, TRAID = Traffic Accident Information Data System, UMTRI = University of Michigan Transportation Research Institute, WSTIP = Washington State Transit Insurance Pool, WTORS = wheelchair tie-down and occupant restraint systems.

Address all correspondence to Greg Shaw, PhD; Center for Applied Biomechanics, University of Virginia, 1011 Linden Ave, Charlottesville, VA 22902; 434-296-7288, ext 130; fax: 434-296-3453. Email: cgs5w@virginia.edu

DOI: 10.1682/JRRD.2007.03.0045 
comply with U.S. Americans with Disabilities Act (ADA) and U.S. Department of Transportation (DOT) standards present problems for both wheelchair riders and transit providers because they are both time-consuming and difficult to operate properly [4-5]. Often these systems are misused or considered too cumbersome to use $[3,6]$. No alternative to strap WTORS has yet emerged that has been proven to satisfy the challenging ADA crash protection standards without hindering the transit process.

The ADA national standard for WTORS was developed without the benefit of adequate information concerning the risk of injury or death to wheelchair riders and with virtually no information concerning the transit bus crash environment. The 1990 ADA that includes requirements for U.S. public transit bus WTORS (architectural and transportation barriers) prescribes strength requirements for the wheelchair tie-downs that were derived from $32 \mathrm{~km} / \mathrm{h}, 8$ to $10 \mathrm{~g}$ frontal barrier crash tests of large transit buses [7-9]. This barrier crash velocity was chosen to represent the average travel speed of a transit bus [10]. Evaluators of a prototype bus seat considered such a crash to be "very severe" [11]. In a recent study by the British Transportation Research Laboratory Ltd, the researchers adopted United Nations Economic Commission for Europe Regulation 80 in their investigation of wheelchair rider protection on "M3" vehicles (vehicles with $>8$ seats and a total mass $>4,500 \mathrm{~kg}$ ) [12]. This regulation, applicable to large transit buses, includes a test protocol for bus seats and seat anchorages that involves a simulated impact with an 8 to $12 \mathrm{~g}$ peak deceleration. However, a previous British study indicated that a $10 \mathrm{~g}$ deceleration level was inappropriate for full-size buses [13].

We have conducted two prior studies in which we reviewed the literature and conducted database searches to determine the crash risk and crash environment for all vehicles that transport wheelchair riders and to determine whether the 8 to $12 \mathrm{~g}$ deceleration crash protection level was appropriate relative to real-world incident data [1415]. We found few studies and limited data collection efforts because of both a lack of adequate data that identify wheelchair-seated occupants and the very low number of kilometers traveled by wheelchair users relative to other bus riders.

Our initial study found few documented cases of injuries to wheelchair riders aboard buses of any kind. Of the estimated annual average of 53,000 wheelchair- related injuries in all settings between 1988 and 1996 [16], about 170 (0.3\%) involved a wheelchair aboard a moving vehicle. Most of these incidents involved the rider falling out of the wheelchair or the wheelchair tipping over or moving during vehicle maneuvers, and only 6 percent of the incidents involved a collision. No wheelchair riders sustained injuries severe enough to require hospital admission [14]. We also found no documented wheelchair rider injuries in transit bus crashes and that transit buses were, along with school buses, the safest form of transportation for the general public.

Our second study also documented the lack of information regarding wheelchair rider events and found very little published information regarding general transit bus safety and crash environments. Our results suggested that wheelchair riders do not face undue risks aboard transit buses. Most reported wheelchair incidents were noncollision events in which a rider was injured because he or she was not restrained properly or the wheelchair was inappropriately secured. The lack of information for wheelchair rider crashes and injuries is likely because wheelchair riders comprise $<0.3$ percent of bus passengers and, presumably, a similarly low percentage of bus passenger kilometers traveled. Studies that span 30 years confirm that the transit bus is an exceedingly safe form of transportation. We found no estimates of crash environment severity in terms of acceleration/deceleration ( $g$ level) in the passenger compartment for incidents involving either wheelchair riders or other passengers. Although most injuries due to collisions have been minor, some are classified as serious; only a few fatalities have been reported. Crash conditions for the apparently rare severe events are not adequately described. Much more information was available for more the commonly occurring noncollision incidents associated with vehicle motion during normal operation and evasive maneuvers. Reported acceleration/deceleration levels for these events ranged from 0.3 to $0.75 \mathrm{~g}$.

Although the results of our second study indicated that protection up to the $0.75 \mathrm{~g}$ level is more justifiable than the 8 to $12 \mathrm{~g}$ level, the study failed to characterize events $>0.75 \mathrm{~g}$. The frequency, severity, and principal impact direction of these events was not established. This information is critical in establishing an appropriate level of crash protection for wheelchair riders. Therefore, this study attempts to characterize large transit bus injuryproducing events, especially crashes that involve deceleration levels $>0.75 \mathrm{~g}$. 


\section{METHODS}

The primary information sources for this study were five U.S. and Canadian databases that contain information on transit bus events, most of which involved a crash or abrupt bus motion. Although the original research plan included representative sampling of transit providers relative to geographic region and traffic density, because of the scarcity of accessible information, I selected databases based on the quality of the information regarding large bus incidents and the level of access I was provided. Figure 1 lists the information items targeted in the databases. Two national U.S. databases were explored: the National Automotive Sampling System General Estimates System (GES) and the Fatality Analysis Reporting System (FARS). The GES provides information on general motor vehicle events and the FARS records events involving a fatality. Three regional databases also were investigated: the Ontario Ministry of Transportation (MOT), the Washington State Transit Insurance Pool (WSTIP), and the New York State DOT (NYSDOT).

Because much of the data comprised small sample sizes from individual transit providers, I was unable to use statistical data analysis methods or validate assumptions that regional data was representative of the United States as a whole. I identified trends and relationships between factors by visual inspection of the data from individual sources.

I analyzed FARS and Ontario MOT database information to estimate transit bus fatality and injury rates, and investigated select FARS cases with crash reconstruction techniques to determine approximate crashseverity levels. The techniques used collision partner vehicle and effective fixed object masses, police-reported travel speeds, angles of impact, skid distances, and road surface conditions to calculate changes in bus velocity $(\Delta V)$, a measure of impact severity.

\section{RESULTS}

\section{U.S. National Databases}

General Estimates System: Transit Bus Damage

The GES provides information on buses involved in crashes in the United States [17]. Unfortunately, the GES does not uniquely identify transit buses but groups them in the "Other bus" vehicle category. In order to separate the data collected for transit buses, I found a similar database,

\begin{tabular}{|c|c|}
\hline Element & Comment \\
\hline Event Type & Crash or noncrash event that affected driver or passengers. \\
\hline Vehicle Damage & $\begin{array}{l}\text { Surrogate for crash severity and basis for approximate } g \text {-level } \\
\text { estimation. Location and extent of damage indicates principle } \\
\text { direction of force. }\end{array}$ \\
\hline $\begin{array}{l}\text { Preimpact Vehicle } \\
\text { Speed }\end{array}$ & $\begin{array}{l}\text { Change in velocity }(\Delta V) \text { of crash indicates crash severity. } \\
\text { While } \Delta V \text { can only be estimated by crash reconstruction, } \\
\text { preimpact speed or posted speed limit is useful in estimating } \\
\text { approximate } \Delta V \text { upper boundary. }\end{array}$ \\
\hline $\begin{array}{l}\text { Collision Partner/ } \\
\text { Object }\end{array}$ & $\begin{array}{l}\text { Large buses must hit or be hit by heavy vehicle (or light } \\
\text { vehicle at high speed) to generate high } g \text { levels. Hitting rigid } \\
\text { roadside object, such as bridge abutment, also can result in } \\
\text { severe event. }\end{array}$ \\
\hline Occupant Injury & $\begin{array}{l}\text { Number and severity of passenger injuries allow estimation of } \\
\text { risk and are also crude indicators of event severity. Driver injury } \\
\text { can also aid in estimating event severity; e.g., event in which } \\
\text { unbelted driver is ejected suggests }>0.75 \mathrm{~g} \text { deceleration. }\end{array}$ \\
\hline
\end{tabular}

Figure 1.

Information targeted from database reviews on transit bus events. 
the Canadian Traffic Accident Information Data System (TRAID), that does include data unique to transit buses. Note that this approach assumes that the ratio of transit buses to intercity buses in the GES is similar to the ratio of transit buses to intercity buses in the Canadian TRAID database. Table 1 summarizes the number and type of reported bus damage events in 1999 in Canada from the TRIAD and between 1999 and 2001 in the United States from the GES.

Transit buses comprised 72.7 percent of the Canadian TRAID “Severe (repair) + demolished” damage category total $(32 / 44=0.727)$ (Table 1). Assuming a similar proportion exists for the corresponding GES damage category yields an annual average of 430 severely damaged transit buses $(0.727 \times 592)$ in the United States. Given the large number of buses with unknown damage, the actual number of severely damaged buses is likely higher. Another reported GES element, "Manner of leaving scene," is also related to crash damage and has fewer data points coded as "Unknown;" for example, the GES database records that 24,480 buses were driven from the crash scene, 1,308 were towed because of damage (in addition to serious damage, buses may be towed because of minor problems, i.e., broken headlight or windshield), 197 were towed but not because of damage, 117 were abandoned, and 163 were unknown. Assuming the same 0.727 ratio of transit buses to intercity buses for this data element yields an annual estimate of $951(0.727 \times 1,308)$ transit buses that were known to be towed because of damage in the United States. In summary, the GES data elements "Damage severity" and "Manner of leaving scene" suggest that annually between 430 and 951 transit buses were substantially damaged in crashes between 1999 and 2001 in the United States.

\section{Fatality-Producing Events Aboard Transit Buses}

The FARS attempts to record every U.S. motor vehicle event that involves a fatality of a vehicle occupant or nonmotorist [18]. Table 2 describes the crash and noncrash events fatal to transit bus drivers and passengers between 1997 and 2001.

Tables 3 and 4 summarize the number of fatalities and the event types. A total of nine drivers and seven onboard passengers were killed in 560 events. Because every FARS case must involve a fatality, this finding indicates that the great majority of fatalities occurred in the collision partner vehicle or involved a pedestrian.

Drivers were more likely to die than passengers despite the average estimated passenger-to-driver ratio of 12:1. This ratio was not derived systematically, but it approximates onboard counts in various transportation studies [19]. The driver station is apparently more dangerous than the passenger area despite the common availability of occupant restraint belts (which were not always used as evidenced by the four cases in which an unbelted driver was ejected). In all but one case, the driver's fatal injuries occurred in a frontal or side crash. In five of eight cases, the damage to the bus was severe and required that the bus be towed from the scene. The percent of severely damaged buses in crash events that involved a driver fatality $(5 / 8=62.5 \%)$ is much higher than the 4.1 percent calculated for general transit bus crashes (severe damage/ $[$ none + minor + moderate + severe $]=592 / 15,056=$ 3.9\%) (Table 1).

Table 1.

Number and severity of bus damage events in Canada in 1999 from Traffic Accident Information Data System (TRAID) database and United States from 1999 to 2001 from General Estimates System (GES) database.

\begin{tabular}{|c|c|c|c|c|c|c|c|}
\hline \multirow[b]{2}{*}{ Year/Database } & \multirow[b]{2}{*}{ Bus Type } & \multicolumn{5}{|c|}{ Damage Event Category (No.) $^{*}$} & \multirow[b]{2}{*}{ Total } \\
\hline & & $\begin{array}{l}\text { None } \\
\text { [None] }\end{array}$ & $\begin{array}{l}\text { Superficial } \\
\text { [Minor] }\end{array}$ & $\begin{array}{l}\text { Moderate Unsafe } \\
\text { [Functional] }\end{array}$ & $\begin{array}{c}\text { Severe } \\
\text { (Repair) + } \\
\text { Demolished } \\
\text { [Disabling] }\end{array}$ & $\begin{array}{c}\text { Unknown + } \\
\text { Not Available } \\
\text { [Unknown] }\end{array}$ & \\
\hline \multirow{3}{*}{$\begin{array}{l}1999 \text { TRAID } \\
\text { (Canada) }\end{array}$} & Transit & 419 & 794 & 171 & 32 & 620 & 2,036 \\
\hline & Intercity & 117 & 271 & 67 & 12 & 181 & 648 \\
\hline & Total & 536 & 1,065 & 238 & 44 & 801 & 2,684 \\
\hline $\begin{array}{l}\text { 1999-2001 GES } \\
\text { (United States) }^{\dagger}\end{array}$ & Other & 3,111 & 6,068 & 5,285 & 592 & 11,210 & 26,266 \\
\hline
\end{tabular}

*TRAID categories collapsed to approximate corresponding GES categories, which are displayed in brackets.

${ }^{\dagger}$ GES counts are U.S. national estimates based on sample of events (National Automotive Sampling System). Data presented as mean/year. 
Table 2.

Fatality Analysis Reporting System database 1997 to 2001: Transit bus case event descriptions. Database was searched for all fatalities of either drivers or passengers that occurred aboard transit bus in either crash or noncrash events.

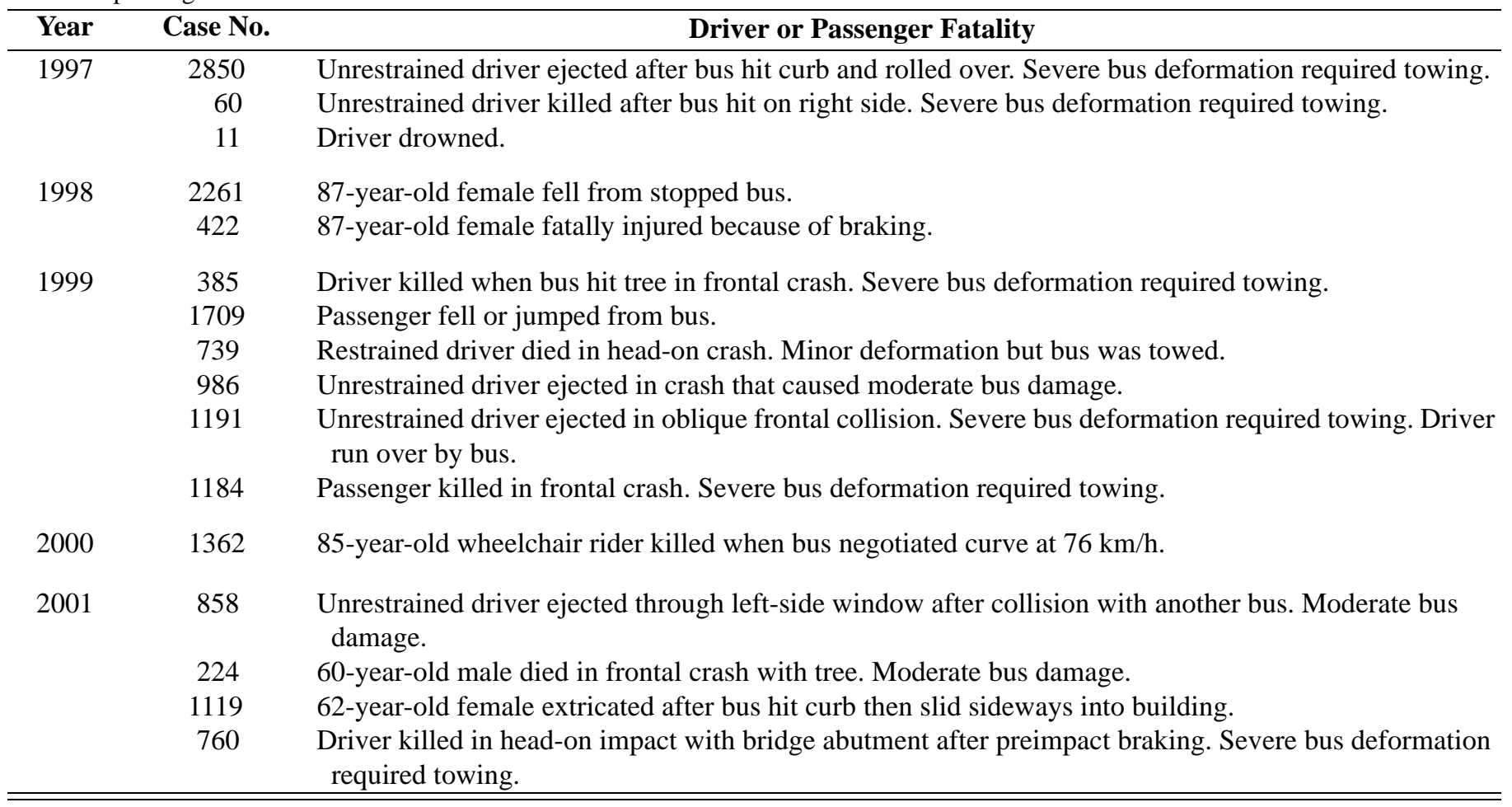

Table 3.

Fatality Analysis Reporting System database 1997 to 2001: Transit bus case fatalities.

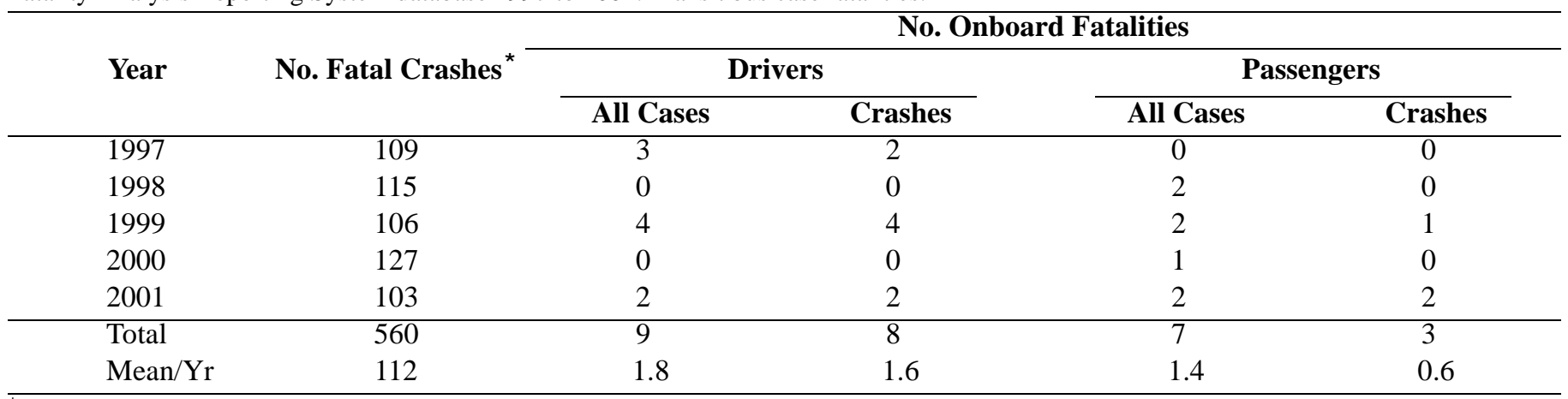

*Fatal crashes include those in which fatally injured was in collision partner vehicle or was pedestrian. One bus per case was involved, with two exceptions in which two buses were involved.

Only three of the seven passenger deaths occurred during crashes, two frontal and one side. Bus crash damage was coded as "Severe" in two cases and "Moderate" in the third. The side-impact event required passenger extrication, which suggests that the bus wall may have intruded into the passenger space. The other four passenger fatalities occurred in noncontact events, two of which involved braking or turning. The sole fatality of a wheel- chair rider, an 85-year-old female, was attributed to a bus executing a turn at relatively high speed.

Of the eleven driver and passenger fatalities that involved crashes, five of the crashes involved immovable objects or a heavy vehicle (Table 2, cases 385, 858, 224, 1119, and 760). One of the driver fatalities involved impact with a bridge abutment, one a frontal impact with a tree, and another an impact with another bus. In one of 
Table 4.

Fatality Analysis Reporting System database 1997 to 2001: Transit bus case fatalities and contact type.

\begin{tabular}{lcc}
\hline \multicolumn{1}{c}{ Contact Type } & $\begin{array}{c}\text { Driver } \\
\text { Fatalities }\end{array}$ & $\begin{array}{c}\text { Passenger } \\
\text { Fatalities }\end{array}$ \\
\hline Frontal & 4 & 2 \\
Side & 2 & 1 \\
Rear & 0 & 0 \\
Other/Unknown & 2 & 0 \\
Noncontact Event & 1 & 4 \\
\hline Total & 9 & 7 \\
\hline \hline
\end{tabular}

the passenger cases, the bus slid sideways into a building, in another, the front of the bus hit a tree.

\section{Regional Databases}

In an attempt to gather additional information on transit bus events, I reviewed three regional databases: the Ontario MOT, the NYSDOT, and the WSTIP.

\section{Ontario Ministry of Transportation Database}

The Ontario MOT database provided a wealth of specific information concerning transit bus events. The Ontario MOT database, like the general Canadian TRAID database, uniquely identifies municipal transit buses rather than including them in an "Other bus" category as in the GES database. Therefore, like the TRAID, I used the Ontario MOT to help characterize U.S. transit bus events. This approach assumes that regionally reported events are representative of those in the United States as a whole, an assumption that was not tested in this study. Other advantages of the Ontario MOT database are that it captures 62 percent of the Canadian transit bus events, it is well documented, and the staff provide generous technical assistance. The 137-field database includes transit bus events that resulted in either injury or property damage $>\$ 1,000$ Canadian and police-reported information on the event, the vehicle, and involved persons. The events are not investigated nor are crashes reconstructed. The Ministry staff provided data on transit bus events from 1999 to 2001.

Event type, bus speed, vehicle damage, and level of personal injury were the main parameters extracted. The Appendix (available online only at http://www.rehab. research.va.gov) defines the data elements used in the analyses. Assuming that $g$ level is related to bus damage and the severity and frequency of occupant injury, I examined these parameters to identify events that most likely involved $g$ levels that exceed those encountered during abrupt braking, turning, and accelerating.

The 1999 to 2001 database review involved 4,292 events and 61,529 bus passengers. The majority of the events involved only property damage and/or injury to other vehicle occupants or pedestrians. Only 580 of these events involved an injury to a bus passenger. A total of 844 passengers were injured. Sixty-six percent of the injuries were minimal; only 0.6 percent were major (requiring hospital admission) (Table 5).

Of the 844 bus passengers injured, the type of event was known for 751 (Table 5). For 49 percent of the passengers, the bus made contact with another vehicle or fixed object. For 51 percent of the passengers, the event did not involve contact. Most of the noncontact events are assumed to have involved bus motion from either normal or emergency maneuvers. Injury severity was not related to bus contact (Figure 2). All the major injuries occurred in noncontact events. For those events that involved contact, the amount of damage to the bus was unrelated to injury severity unless the bus was described as "Demolished" (Figure 3).

Table 6 summarizes the five contact events in which the bus was considered "Demolished" (damaged so severely

Table 5.

Ontario Ministry of Transportation database 1999 to 2001: Injury severity and event type for injured passengers $(n=844)$. Database contained a total of 4,292 events and 61,529 passengers in all events.

\begin{tabular}{lcrrr}
\hline \multirow{2}{*}{ Injury Type } & \multirow{n}{*}{$(\mathbf{\%})$} & \multicolumn{2}{c}{ Event Type (No.) } & \multirow{2}{*}{ Total } \\
\cline { 3 - 4 } & & Contact & Noncontact & 507 \\
Minimal & $554(66)$ & 247 & 260 & 239 \\
Minor & $285(34)$ & 124 & 115 & 5 \\
Major & $5(0.6)$ & 0 & 5 & 0 \\
Fatal & $0(0)$ & 371 & 0 & $751^{*}$ \\
Total & $844(100)$ & 380 & 0 \\
\hline
\end{tabular}

${ }^{*}$ Event type unknown for 93 of 844 injured passengers. 


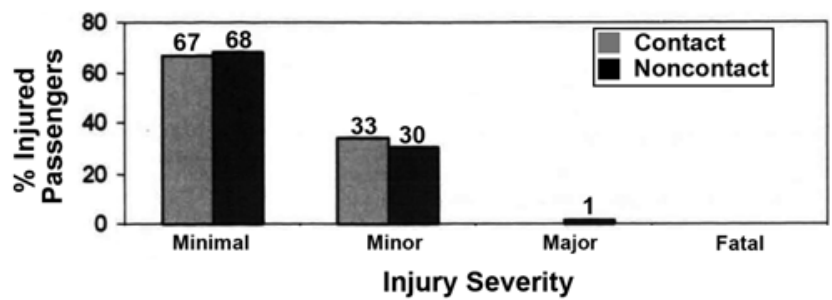

Figure 2.

Ontario Ministry of Transportation database 1999 to 2001:\% of passengers injured in contact and noncontact events and severity of their injuries.

as to be uneconomical to repair). In these events, nearly all the passengers aboard were injured (an average of 92\%). In events in which less bus damage occurred, the percent of injured passengers decreased (Figure 4). In four of the five events, frontal contact was the primary impact. In one event that involved a bus being hit from the right side, one injured passenger was partially ejected.

The events involving contact are further characterized in Figures 5 and 6. Visual inspection of the results suggests that injury severity is not strongly associated with estimated preevent bus speed (Figure 5). Three of the five major injuries occurred at speeds of $<5 \mathrm{~km} / \mathrm{h}$. The percent of minor versus minimal injuries increased when speeds exceeded $30 \mathrm{~km} / \mathrm{h}$.

In cases in which $\geq 1$ passenger was injured, impacts to the front of the bus were the most common (Figure 6). Collectively, frontal impacts comprised 57 percent of all impacts, rear impacts 24 percent, and left- and right-side impacts 19 percent. The single most heavily contacted area was the left front corner, which accounted for 25 percent of the impacts.

The following is a summary of Ontario MOT database findings:

1. The Ontario MOT database review provided additional evidence of transit bus safety. No onboard fatalities and only five major injuries were reported in the 3 years studied.

2. Injury frequency and severity were very similar for contact versus noncontact events, such as vehicle maneuvers.

3. Bus damage was associated with injury for only five cases in which the bus was considered "Demolished." Most of the passengers were injured. Four of these five cases involved impacts to the front of the bus.

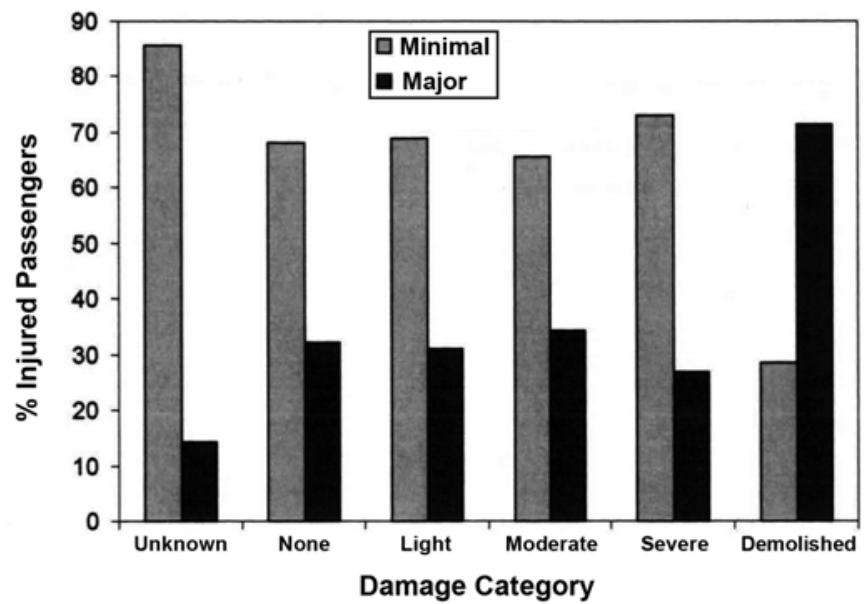

Figure 3.

Ontario Ministry of Transportation database 1999 to 2001: Relationship between passenger injury severity and bus damage for contact events.

4. Most (57\%) injury-producing contacts were to the front of the bus.

5. Preevent bus speed was not strongly associated with injury.

\section{New York State Department of Transportation Database}

The NYSDOT is the only state DOT that systematically records and investigates transit bus events. In contrast to the Ontario MOT database review, I did not have access to the underlying data but relied on NYSDOT personnel to conduct database searches on my behalf. I explained the need to identify severe transit bus events and requested cases that involved bus crashes and resulted in bus occupant injuries and deaths. Table 7 summarizes the NYSDOT response, which is a sampling of case reports selected by an experienced staff member and is not intended to be a census of such events.

Three cases did not involve a crash but an abrupt evasive maneuver. Braking was reported in three of the noncrash events for which insufficient details were available to determine if the passenger injuries were sustained during the preimpact braking or the subsequent crash. Although two drivers died, no passengers were killed or suffered injuries severe enough to require hospital admission.

Summary of NYSDOT database findings:

1. No passengers were killed or suffered injuries severe enough to require hospital admission. 
Table 6.

Ontario Ministry of Transportation database 1999 to 2001: Contact events involving a demolished bus.

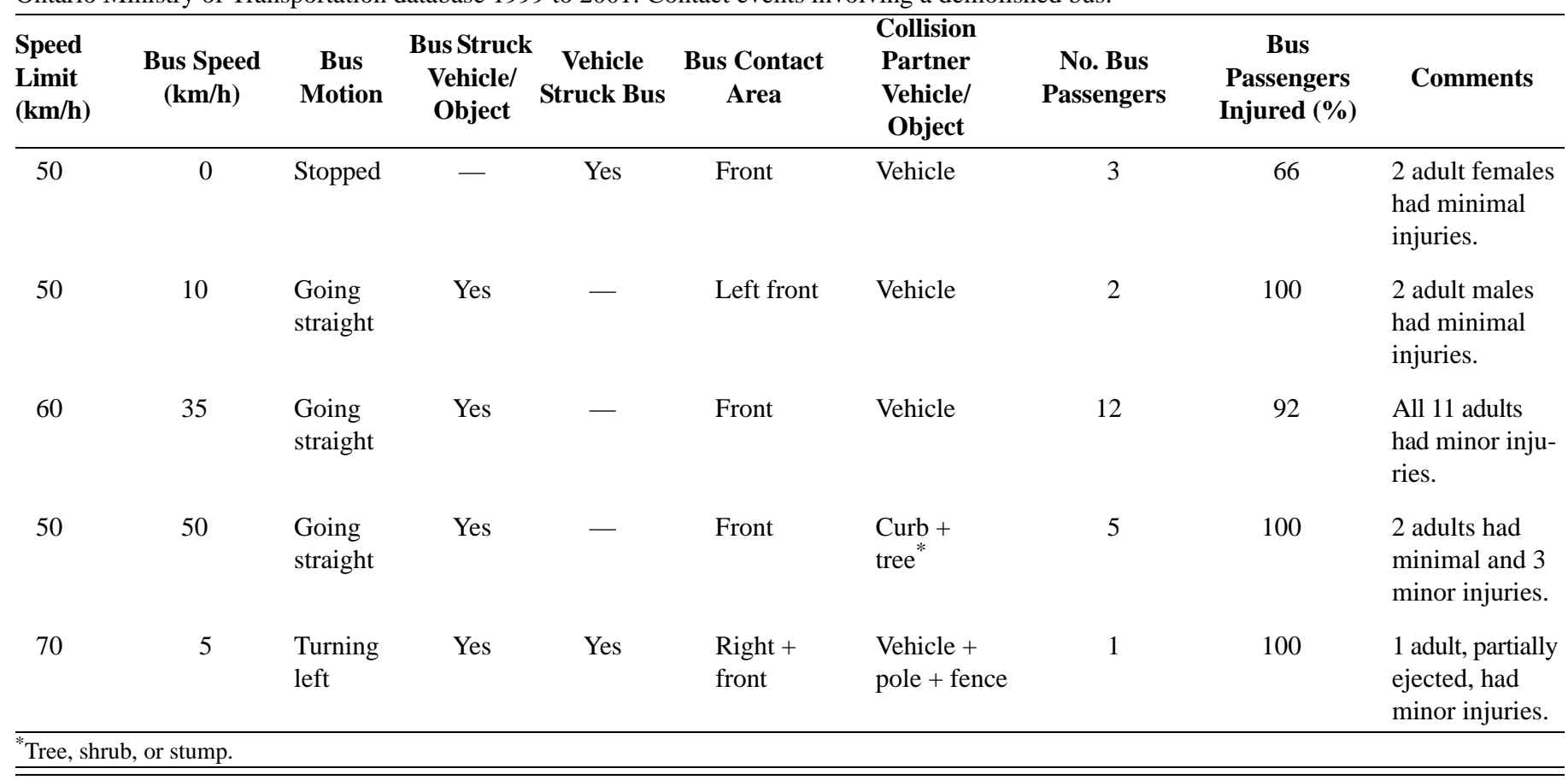

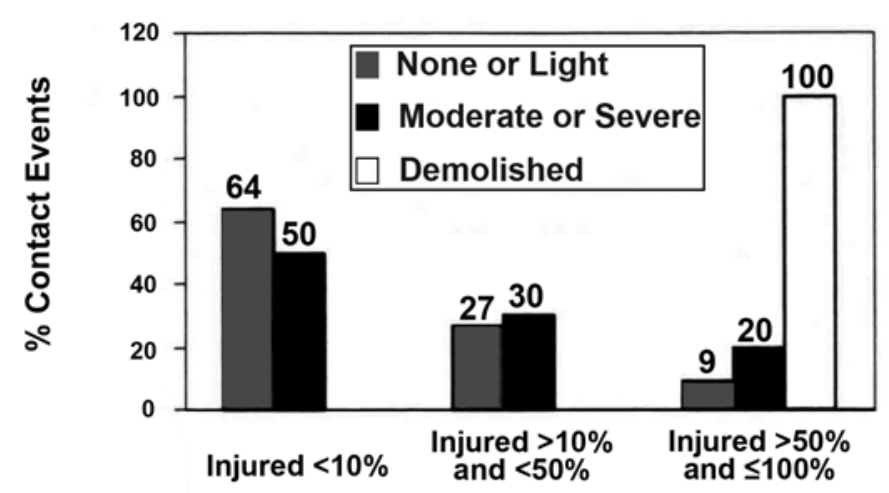

Figure 4.

Ontario Ministry of Transportation database 1999 to 2001: \% of 580 contact events in which 1 passenger was injured as function of $\%$ injured passengers ([injured/uninjured] $\times 100$ ) and bus damage; e.g., in $64 \%$ of events, \% of injured passengers was $<10$ when bus damage was described as "None or Light."

2. Of the four crash events, two involved impacts to the front of the bus, one to the side, and one involved a side impact followed by a frontal impact.

3. Avoidance maneuvers caused injuries in several noncrash cases. In one case (5606), preimpact braking caused a passenger to fall from the vehicle seat.
4. Five of the seven events involved abrupt braking; in two cases (5606 and 6102), the braking preceded the crash.

\section{Washington State Transit Insurance Pool Database}

The WSTIP maintains a database of claims for 19 transit properties in the Northwest, including one transit organization in Ohio. In contrast to the other database reviews, this review included both fixed-route transit buses and on-demand van-based buses (e.g., paratransit vans). WSTIP generously provided data for 1,333 injury and property claims recorded between 1996 and 2003. Of the 1,333 cases, only 162 (12\%) involved a crash: 147 claims involved a fixed-route bus crash, 15 involved a van crash, and 53 involved wheelchair riders, although none of the more costly wheelchair rider claims involved a transit bus crash (Table 8).

Although the database does not indicate whether the claim event monetary totals were due to property damage or injury or a combination thereof, the WSTIP staff suggested that claims $>\sim \$ 10,000$ usually indicate an injury was involved. The location of the injured claimant was not recorded, and the claimant could have been in a collision partner vehicle. Twenty-nine fixed-route buses and 


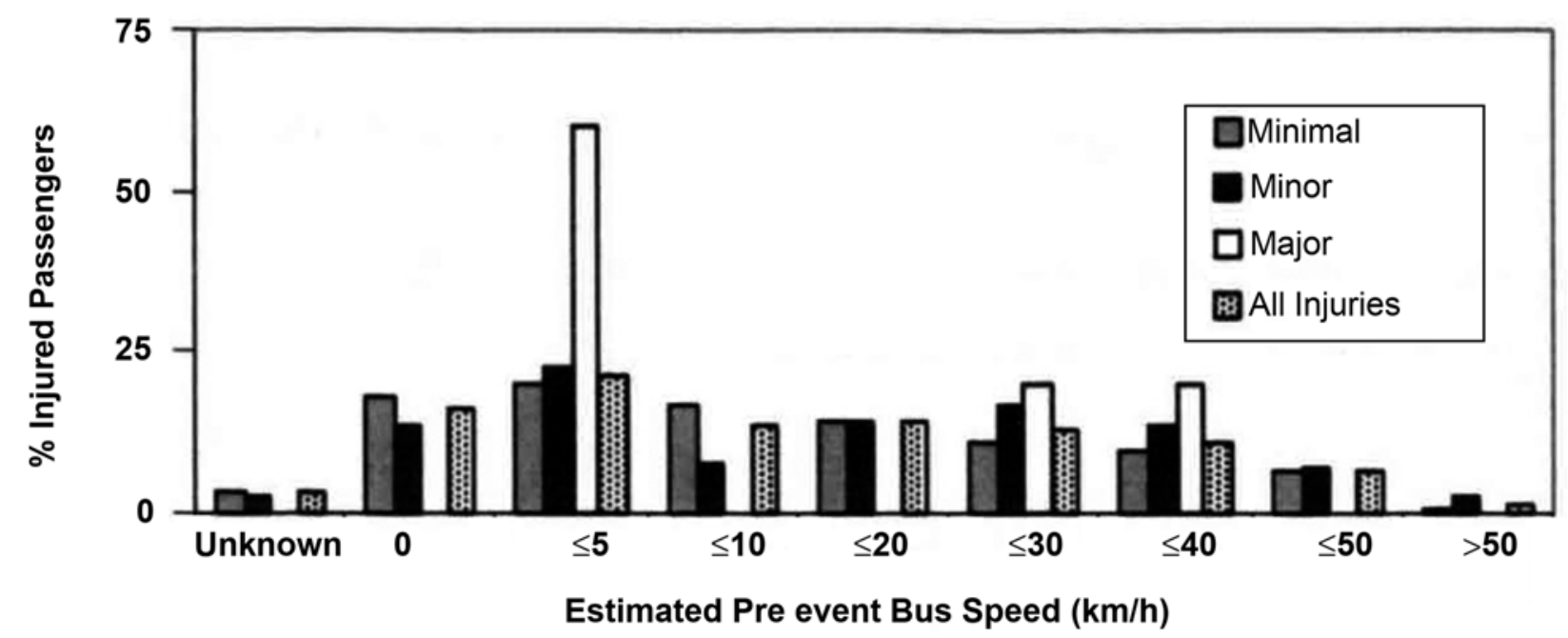

Figure 5.

Ontario Ministry of Transportation database 1999 to 2001: \% of passengers injured in both contact and noncontact events, injury severity, and estimated preevent bus speed.

one van were involved in claims $>\$ 9,500$ (Tables 8 and 9). The majority of these claims involved a bus crash (17/29).

WSTIP provided detailed information for the most severe crash that involved a fixed-route transit bus whose driver passed out from an apparent heart attack in March 1999. The bus, with 36 passengers onboard, hit concrete barriers with its left and right front corners injuring 22 passengers and the driver. The driver and 13 passengers were taken to area hospitals. Passengers interviewed at the hospital described "a scene of bodies flying around and a lot of chaos.” The passengers, suffering no serious injuries, were all treated and released. The front of the bus was extensively damaged (Figure 7). Estimated bus repair costs were $\$ 41,000$ excluding replacement parts.

Eleven cases did not involve a crash. Six of these cases (four nonwheelchair riders and two wheelchair riders) involved braking.

Table 10 outlines the four wheelchair rider incidents (two that did not involve a crash and two that did) and the associated claim costs. The average wheelchair rider claim cost for claims $>\$ 9,500$ was $\$ 65,496$, which is 60 percent higher than that of the average claim for nonwheelchair riders $(\$ 41,059)$. All four of the noncrash wheelchair events were among the 10 most costly event types despite having only one or two claimants per event (Table 11). The ratio of wheelchair rider claims $>\$ 9,500$ to other rider claims $(4 / 29=0.14)$ is much higher than the 0.0024 ratio of wheelchair riders to general riders estimated for Seattle, a city with a large percentage of wheelchair riders [15]. The ratio of all wheelchair rider claims to other rider claims $(53 / 1,333=0.04)$ is also much higher than this estimated ratio of wheelchair riders to general riders.

The following is a summary of WSTIP database findings:

1. During the study period, 12 percent of the property and injury claims involved a crash. A transit bus was involved in 147 of the crashes and a van or paratransit vehicle in 15.

2. A severe crash, as evidenced by extensive bus damage and passengers being thrown out of their seats, injured 22 of the 36 passengers but caused no serious injuries.

3. The four wheelchair rider claims $>\$ 9,500$ occurred aboard a paratransit vehicle and did not involve a crash. The average wheelchair rider claim event monetary total was higher than that for general riders.

4. A disproportionate number of substantial $(>\$ 9,500)$ wheelchair rider claims were noted compared with the ratio of wheelchair riders to other riders of transit buses and vans.

\section{Analysis of Database Information}

\section{Fatal and Nonfatal Injury Rates}

Fatality rate, expressed as deaths per 100 million passenger kilometers, is a widely used metric to describe the risk associated with a mode of transportation. The 


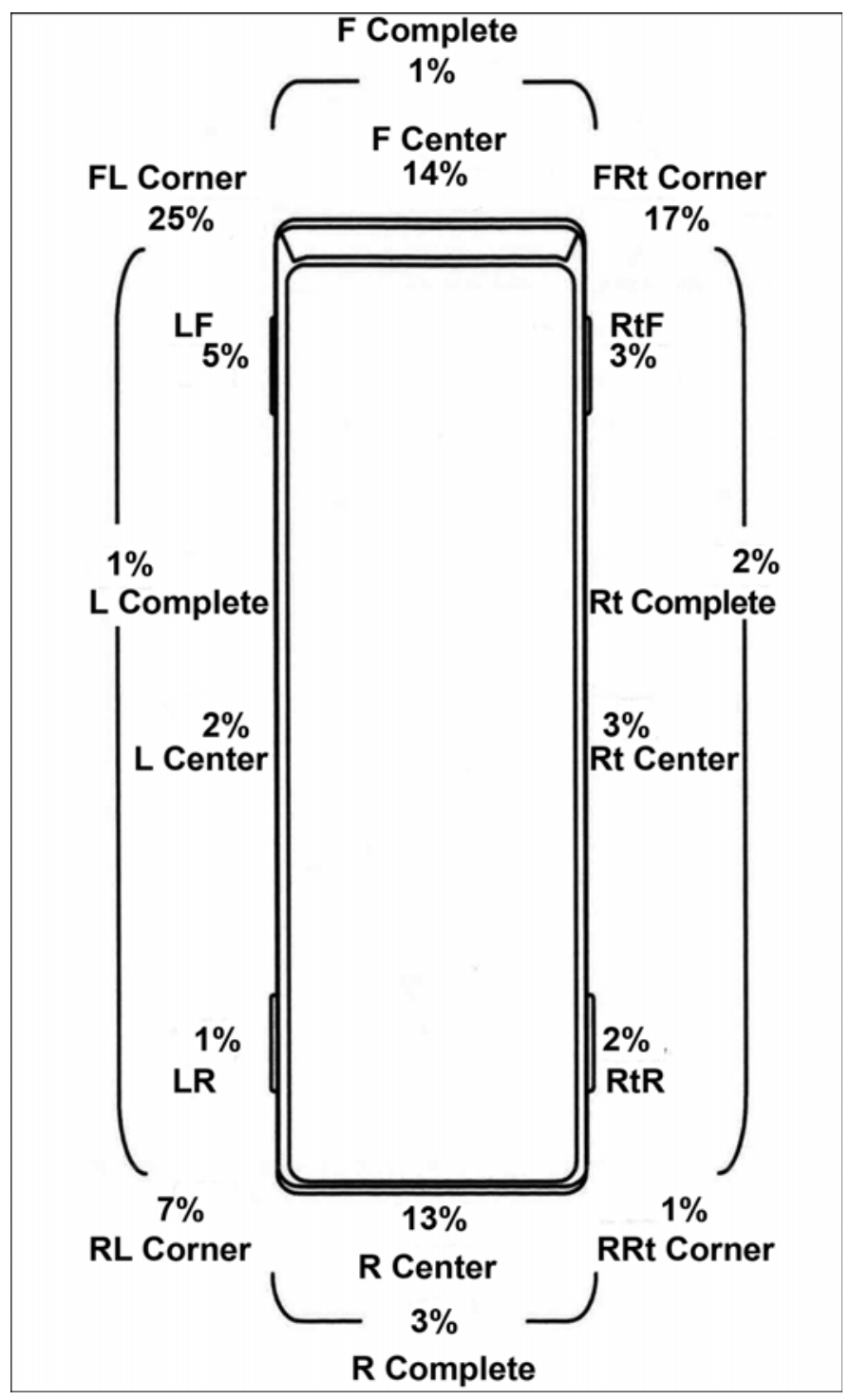

Figure 6.

Ontario Ministry of Transportation database 1999 to 2001: Distribution of impact location for 269 cases for which contact occurred and location was known and 1 bus passenger was injured. $\mathrm{F}=$ front, $\mathrm{L}=$ left, $\mathrm{R}=$ rear, $\mathrm{Rt}=$ right.

National Safety Council (NSC) calculates the fatality rate using FARS data and passenger kilometer data from the American Public Transit Association (Table 12) [20]. I also calculated the fatality rate using a combination of FARS data and NSC Safety Management Information Statistics passenger kilometer data for "passenger fatalities due to all causes.”

The FARS analysis finding of 0.006 fatalities per 100 million passenger kilometers is similar to the 0.004 rate calculated by the NSC. Our analysis identified only one onboard fatality in the 3-year study period due to a transit bus crash. This rate translates to an average annual rate of 0.001 , a quarter of the NSC rate for onboard passenger fatalities in all transit bus events (Table 12). Note that the average annual fatality rates are based on very few annual fatalities and can change substantially if a single year with several fatalities is included or excluded from the calculation.

In addition to fatality rates, I also estimated onboard transit bus nonfatal injury rates and the number of annual injuries in the United States using Ontario MOT data. Table 13 and Figure 8 summarize the relationship between injury frequency and severity. As expected, as injury severity increases, frequency decreases. The rate of minor injuries, those that do not require hospital admission (2.603), is approximately half that of minimal injuries (5.060). In turn, the rate for major injuries that do require hospitalization (0.046) is less than one-fifth the rate of minor injuries. Table 13 presents an estimate of the number of onboard transit bus passenger injuries in the United States extrapolated from the Ontario MOT injury data. The results suggest that only 19 major injuries occur annually.

\section{Transit Bus Crash Event g-Level Determination}

A major focus of this study was characterization of bus crashes in terms of onboard $g$ levels. In addition to using database bus damage and passenger injury as very general indicators of crash $g$ level, we corroborated with University of Michigan Transportation Research Institute (UMTRI) researchers to estimate $g$ levels using crash reconstruction techniques for select FARS cases [21].

UMTRI identified 33 transit buses cases in which passengers and/or the driver sustained injuries recorded in the FARS database for 1999. For inclusion in FARS, a transit bus event must involve a death. In all of these cases, the death occurred external to the bus.

We analyzed nine cases for which the relative velocity of the bus/collision partner was known and the impact was to the front or to the side of the bus in order to allow comparisons to the Calspan bus crash test results (Tables 14 and 15, Figure 9) [22].

Eight of the nine cases involved the front of the bus hitting a passenger vehicle either in the side (four) or in the front (four head-on impacts) (Table 16). One case involved a car hitting the side of a bus at an intersection. Relative velocity in combination with vehicle masses, an indicator of crash severity, ranged from 35 to $193 \mathrm{~km} / \mathrm{h}$. Some of the crash severities were more than twice that of 
Table 7.

New York State Department of Transportation database 1999 to 2001: Select transit bus cases.

\begin{tabular}{|c|c|c|c|}
\hline $\begin{array}{l}\text { Case } \\
\text { No. }\end{array}$ & Event Type & Summary & Comment \\
\hline 5606 & Crash & $\begin{array}{l}\text { Estimated bus travel speed } 37 \mathrm{~km} / \mathrm{h} \text {, after braking } \\
24 \mathrm{~km} / \mathrm{h} \text {. } 40 \text {-passenger bus }{ }^{*} \text { rotated left after hit } \\
\text { by left-moving fire truck. Unbelted driver killed. } \\
\text { Bus continued moving after impact until wheel hit } \\
\text { raised median causing sudden stop. } 3 \text { passengers } \\
\text { treated and released. }\end{array}$ & $\begin{array}{l}\text { Preimpact braking caused } 1 \text { passenger to } \\
\text { fall from seat. }\end{array}$ \\
\hline 6102 & Crash & $\begin{array}{l}\text { Right front corner of fire truck traveling at } 24 \mathrm{~km} / \mathrm{h} \\
\text { hit left front corner of } 40 \text {-passenger bus at inter- } \\
\text { section. Bus traveling at estimated } 24 \mathrm{~km} / \mathrm{h} \text {, } \\
\text { slowed to } 16 \mathrm{~km} / \mathrm{h} \text { when entered intersection. } \\
\text { Impact spun bus right. Driver and } 10 \text { passengers } \\
\text { treated and released. }\end{array}$ & Preimpact braking for both vehicles. \\
\hline 6402 & Crash & $\begin{array}{l}\text { 36-passenger bus traveling from } 40-48 \mathrm{~km} / \mathrm{h} \\
\text { broadsided SUV with right front corner, then hit } \\
\text { concrete staircase with driver-side front corner. } \\
\text { Driver was ejected through windshield. Unbelted } \\
\text { driver sustained serious injuries. } 3 \text { passengers } \\
\text { were treated and released. }\end{array}$ & $\begin{array}{l}\text { Extensive damage to front and undercar- } \\
\text { riage. No preimpact braking. }\end{array}$ \\
\hline 6558 & Braking $^{\dagger}$ & $\begin{array}{l}40 \text {-passenger bus traveling at } 32 \mathrm{~km} / \mathrm{h} \text { skidded to } \\
\text { stop to avoid taxi cab. Several passengers fell to } \\
\text { floor. Driver and } 6 \text { of } 40 \text { passengers were injured. } \\
2 \text { passengers refused treatment. Driver and others } \\
\text { were treated and released. }\end{array}$ & - \\
\hline
\end{tabular}

*Bus seating capacity: 35-45 seats considered "standard” large transit bus.

${ }^{\dagger}$ Noncrash.

the Calspan offset frontal crash test, which employed an $1,800 \mathrm{~kg}$ bullet vehicle traveling at $90 \mathrm{~km} / \mathrm{h}$ [22].

\section{Transit Bus Crash Tests}

Onboard acceleration data for a variety of defined crash types is needed to estimate bus passenger compart- ment acceleration in real-world crashes. After a prolonged search, we found only a few reports of transit bus crash tests in which bus acceleration was recorded. Instrumented tests of transit buses are rarely conducted. Tests conducted by Calspan Corporation (Buffalo, New York) were well documented and provided the best data 
JRRD, Volume 45, Number 1, 2008

Table 8.

Washington State Transit Insurance Pool database 1996 to 2003: Claims.

\begin{tabular}{llcc}
\hline \multicolumn{1}{c}{ Claim Type } & \multicolumn{1}{c}{ Bus Type } & Count & \multicolumn{1}{c}{ Comment } \\
\hline Total Claims & $\begin{array}{l}\text { Fixed route and demand } \\
\text { responsive (paratransit) }\end{array}$ & 1,333 & $\begin{array}{l}\text { Includes claims for minor and major } \\
\text { incidents. Claimants may have been } \\
\text { aboard transit bus/van, in collision } \\
\text { partner vehicle, or pedestrians. } \\
\text { Includes one fixed-route van. }\end{array}$ \\
$\begin{array}{l}\text { Claims }>\$ 9,500 \\
\begin{array}{l}\text { Crashes Involving Contacting } \\
\text { Vehicle or Fixed Object }\end{array}\end{array}$ & $\begin{array}{l}\text { Fixed route } \\
\text { Fixed route }\end{array}$ & 29 & 147 \\
$\begin{array}{l}\text { Wheelchair Riders Aboard } \\
\text { Fixed Route Buses and } \\
\text { Paratransit Vans }\end{array}$ & -15 & 53 & $\begin{array}{c}\text { None involved crashes on fixed-route } \\
\text { buses. }\end{array}$ \\
\hline \hline
\end{tabular}

Table 9.

Washington State Transit Insurance Pool database 1996 to 2003: Fixed-route claims $>\$ 9,500$.

\begin{tabular}{lc}
\hline \multicolumn{1}{c}{ Event Type } & Count \\
\hline Bus Crash & 17 \\
Van Crash & 1 \\
Noncrash & \\
Bus Braked & 4 \\
Bus Accelerated & 1 \\
Bus Slid Laterally & 1 \\
$\quad$ Driver Rudeness & 1 \\
Wheelchair Bus or Van (all noncrash) & 4 \\
\hline Total & 29 \\
\hline
\end{tabular}

to allow a very approximate estimation of the $g$ level in the case events [22]. The Calspan tests involved impacting a stationary bus with an $1,800 \mathrm{~kg}$ passenger car. The four buses, weighing 10,700 to $14,900 \mathrm{~kg}$, consisted of one representative commercial transit bus, GM New Look (General Motors Corp; Detroit, Michigan), and three Transbus prototypes (GMC Transbus [General Motors Corp], Rohr Transbus [Rohr, Inc; Chula Vista, California], and AM General Transbus [AM General; South Bend, Indiana]) developed in the early 1970s to demonstrate improved safety [22]. Each bus was struck by a car in the front and in the side. Calspan bus tests were conducted for the front bumper, offset frontal impact, and side impact at 16, 90, and $40 \mathrm{~km} / \mathrm{h}$ car impact speeds, respectively. The bullet car was a full-size U.S. sedan that weighed $1,800 \mathrm{~kg}$.

Peak acceleration varied considerably in the sideimpact tests (2.0-12.5 g). Variability was also evident for the $10 \mathrm{~ms}$ acceleration. In all tests, the bus was displaced laterally and sustained permanent deformation of the sidewall. The low-speed bumper tests produced acceleration levels that did not rise above $2.2 \mathrm{~g}$ (Table 14, Figure 9). The high-speed offset frontal impacts produced the highest acceleration with a peak of $21 \mathrm{~g}$ for the Rohr Transbus (Table 15). Acceleration peaks that would be more likely to affect WTORS, such as the 5 and 10 ms values, were considerably lower in most of the tests, averaging $6.3 \mathrm{~g}$ for the front floor $5 \mathrm{~ms}$ acceleration value and $3.2 \mathrm{~g}$ for the front floor $10 \mathrm{~ms}$ value. Accelerations recorded on the floor in the rear of the bus were lower than those recorded nearer to the point of impact in the front of the passenger compartment (Figure 9). Despite the engaged parking brake, the impact drove the buses rearward 99 to $674 \mathrm{~cm}$ and permanently deformed their bumpers 15 to $35 \mathrm{~cm}$.

Table 16 summarizes the $g$-level estimates for the nine cases based on Calspan data. We estimated that peak front-floor acceleration was $<13 \mathrm{~g}$ in four frontal impact cases and $>13 \mathrm{~g}$ in another four. This break point was chosen because the average peak acceleration for the four Calspan buses was $12.7 \mathrm{~g}$ in the offset frontal test (Table 15). The average 5 and $10 \mathrm{~ms}$ duration peaks were 6.5 and 3.1 $g$, respectively. In one case (419), the peak acceleration may have been less than the $1.7 \mathrm{~g}$ that was recorded in the Calspan bumper test. The one side-impact case (428) was much more severe than the Calspan side-impact test because of higher car speed and mass (Table 16).

More recent tests conducted for Transport Canada involved four impacts where the front of a stationary $10,000 \mathrm{~kg}$ transit bus was impacted by a $1,700 \mathrm{~kg}$ car traveling at approximately $48 \mathrm{~km} / \mathrm{h}$, a condition considered to "generate higher occupant loadings and give an indication of the upper reaches of the range" [23]; floor-mounted 


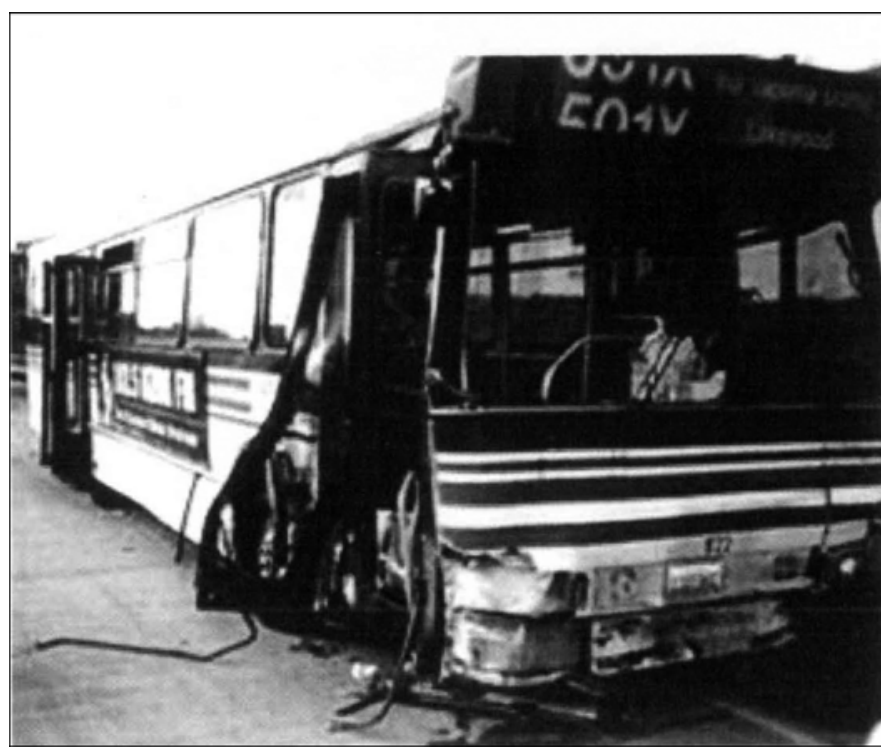

Figure 7.

Washington State Transit Insurance Pool: Most severe crash involved fixed-route transit bus whose driver passed out from apparent heart attack in March 1999. Bus with 36 passengers hit concrete barriers with left and right front corners, injuring 22 passengers and driver. Driver and 13 passengers were taken to area hospitals. Passengers interviewed at hospital described "a scene of bodies flying around and a lot of chaos.” Passengers, suffering no serious injuries, were all treated and released. Front of bus was extensively damaged. Estimated bus repair costs were $\$ 41,000$ excluding replacement parts.

accelerometers indicated that the 10 ms duration bus longitudinal peak acceleration did not exceed $3 g$.

\section{DISCUSSION}

As in our previous studies, the database searches yielded few wheelchair rider events [14-15]. The transit bus is a very safe mode of transportation for the general ridership [11,24-26]. Very limited data are available concerning the injurious events that do occur $[10,15]$. We examined events that involved other riders to estimate the environment to which wheelchair users, had they been present, would have been exposed.

The FARS analysis confirmed NSC data that indicated a very low fatality rate for transit buses. The analysis also found an even lower rate for events that involved a crash. The injury analysis provided additional evidence of transit bus safety. Extrapolation of Ontario MOT injury data suggests that only 19 of the approximately 4.6 billion passengers in the United States (1993 estimate) [27] are admitted annually to hospitals because of injuries sustained while onboard a transit bus.

\section{Transit Bus Passenger Compartment $g$ Level and Injury}

The $g$-level determination effort was motivated by a desire to examine the relatively few injury-producing transit bus events and characterize the event conditions, primarily in terms of passenger compartment $g$ level. This parameter, used to quantify crash severity and an indicator of injury risk, is also useful in establishing criteria for occupant safety systems [28].

The relationship between $g$ level and passenger injury proposed here assumes the following:

1. Most injuries are sustained when the bus contacts another vehicle or roadside object and the passengers are thrown into interior components. For example, in a frontal collision, the bus itself abruptly slows but the unrestrained seated or standing passengers continue to move forward until striking seat backs, stanchions, or the fare box.

Table 10.

Washington State Transit Insurance Pool database 1996 to 2003: Wheelchair rider claims $>\$ 9,500$. Mean of all claims was $\$ 65,496$.

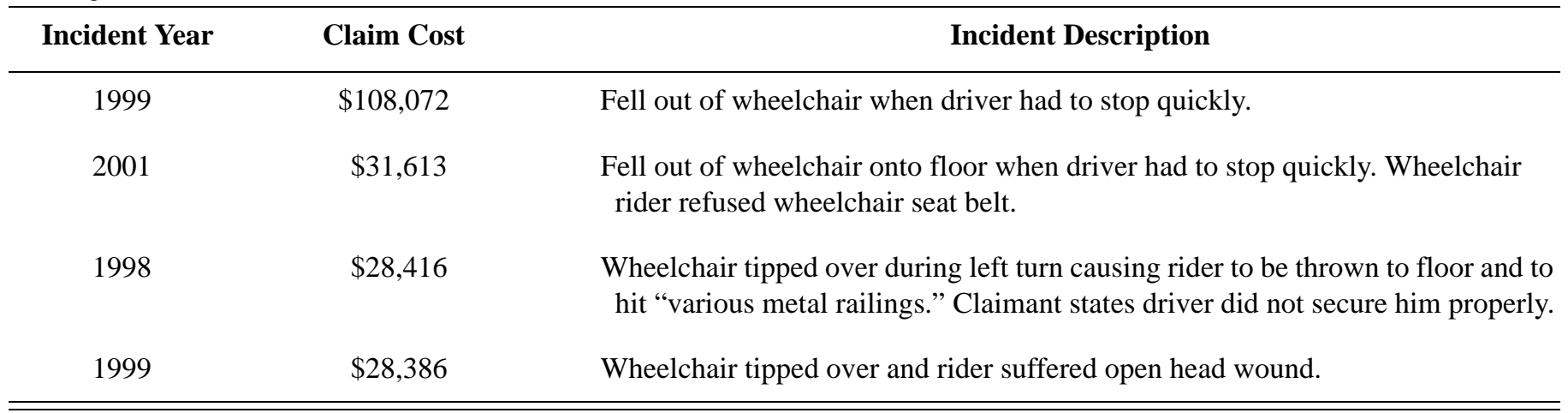


Table 11.

Washington State Transit Insurance Pool database 1996 to 2003: Ten most costly claims.

\begin{tabular}{cclr}
\hline Incident Year & Claim Cost & \multicolumn{1}{c}{ Event Type } & Number of Claimants \\
\hline 1999 & $\$ 538,059$ & Bus crash & 29 \\
1999 & $\$ 108,072$ & Wheelchair bus or van & 1 \\
1999 & $\$ 56,603$ & No crash, bus braked & 1 \\
1998 & $\$ 42,027$ & Van crash & 4 \\
1996 & $\$ 32,827$ & Bus crash & 2 \\
2001 & $\$ 31,613$ & Wheelchair bus or van & 1 \\
1998 & $\$ 28,416$ & Wheelchair bus or van & 1 \\
1999 & $\$ 28,386$ & Wheelchair bus or van & 5 \\
2001 & $\$ 28,366$ & No crash, bus accelerated & 4 \\
2000 & $\$ 27,466$ & Bus crash & \\
\hline \hline
\end{tabular}

Table 12.

National Safety Council (NSC) and Fatality Analysis Reporting System (FARS) databases: Transit bus passenger fatality rate per 100 million passenger kilometers.

\begin{tabular}{|c|c|c|c|c|c|c|c|}
\hline \multirow{3}{*}{ Year } & \multirow{3}{*}{$\begin{array}{l}\text { Passenger } \\
\text { Kilometers* }\end{array}$} & \multirow{2}{*}{\multicolumn{2}{|c|}{$\begin{array}{c}\text { NSC }^{\dagger} \text { Passenger Fatalities: } \\
\text { All Causes }\end{array}$}} & \multicolumn{4}{|c|}{ FARS ${ }^{\text {I }}$} \\
\hline & & & & \multicolumn{2}{|c|}{$\begin{array}{c}\text { Passenger Fatalities: } \\
\text { All Causes }\end{array}$} & \multicolumn{2}{|c|}{$\begin{array}{c}\text { Passenger Fatalities: } \\
\text { Crashes }\end{array}$} \\
\hline & & Count & $\begin{array}{l}\text { Fatality } \\
\text { Rate }^{\ddagger}\end{array}$ & Count & $\begin{array}{l}\text { Fatality } \\
\text { Rate }\end{array}$ & Count & $\begin{array}{l}\text { Fatality } \\
\text { Rate }\end{array}$ \\
\hline 2000 & $30,466,941,406$ & 1 & 0.003 & 1 & 0.003 & 0 & 0.000 \\
\hline 1999 & $30,369,984,523$ & 1 & 0.003 & 2 & 0.007 & 1 & 0.003 \\
\hline 1998 & $29,064,597,333$ & 2 & 0.007 & 2 & 0.007 & 0 & 0.000 \\
\hline Mean & $29,967,174,421$ & 1.33 & 0.004 & 1.67 & 0.006 & 0.33 & 0.001 \\
\hline
\end{tabular}

${ }^{*}$ Passenger kilometers from NSC Safety Management Information Statistics database include both directly operated and purchased transportation data.

${ }^{\dagger}$ NSC rate for 2001 calculated using 34.4 billion passenger kilometers.

${ }^{\ddagger}$ Fatality rate $=$ deaths per 100 million passenger kilometers.

"Calculated from FARS data.

Table 13.

Fatality Analysis Reporting System (FARS) and Ontario Ministry of Transportation (MOT) databases: Fatal and nonfatal injury rates and estimated number of annual onboard transit bus injuries in United States.

\begin{tabular}{|c|c|c|c|c|c|}
\hline \multirow{2}{*}{ Rate/No. } & \multicolumn{4}{|c|}{ Ontario MOT* Injury Type } & \multirow{2}{*}{$\begin{array}{c}\text { FARS }^{\dagger} \\
\text { Injury Fatal }\end{array}$} \\
\hline & All & Minimal & Minor & Major & \\
\hline $\begin{array}{l}\text { Mean/100 million } \\
\text { Passenger km }\end{array}$ & 7.708 & 5.060 & 2.603 & 0.046 & 0.006 \\
\hline $\begin{array}{l}\text { Ontario MOT } \\
\text { Annual Mean }\end{array}$ & 281 & 185 & 95 & 2 & - \\
\hline $\begin{array}{l}\text { Estimated Annual } \\
\text { U.S. Mean }\end{array}$ & 2,630 & 1,727 & 885 & 19 & - \\
\hline \multicolumn{6}{|c|}{ 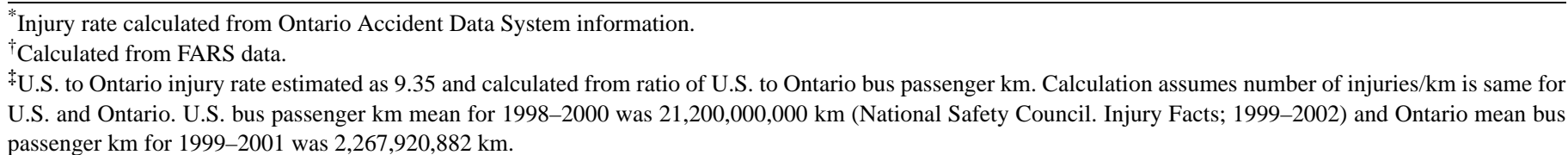 } \\
\hline
\end{tabular}




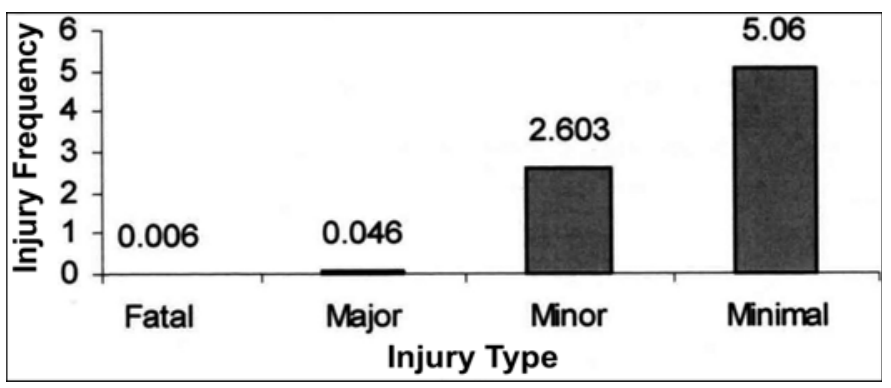

Figure 8.

Ontario Ministry of Transportation database 1999 to 2001: Injury rate per 100 million passenger kilometers.

2. The force with which the passengers strike interior components and the resulting injuries are proportional to the severity of the bus impact as measured by the $g$ level in the passenger compartment, which is related to visible damage to the bus exterior.

\section{Peak Acceleration Estimates and Injuries}

In most of the cases reconstructed for the transit bus $g$-level determination effort in which the number of occupants and the number of injured occupants were known, at least half were injured (Table 17). A large proportion of injured occupants were also recorded for Ontario MOT passengers aboard buses that were demolished. However, except for one "Incapacitating" injury, all the known injuries were minor, with GES labels of "Possible" or "Evident but not incapacitating." Although the GES coding system does not indicate whether hospitalization was required, these results suggest that very few of those injured required admission to the hospital.

Several cases were identified in which the peak onboard acceleration exceeded the $0.75 \mathrm{~g}$ level associated with sudden braking. Although actual $g$ levels were impossible to determine with the limited available case information and crash test data, this analysis suggests that half of the frontal impacts involved peak front floor acceleration $>\sim 13 \mathrm{~g}$. The number of certain injuries ("Evident but nonincapacitating" and "Incapacitating") did not seem to be related to the estimated $g$ level in this admittedly small sample. Only one case in the " $<13 g$ " classification (141) and one case in the ">13 $g$ " classification (418) included an "Evident but nonincapacitating" injury. The most injurious case (428) was estimated to involve a peak $g$ level that exceeded 5.8 and included three "Evident but nonincapacitating" injuries and the only "Incapacitating” injury (Table 16).

\section{Transit Bus Damage and Injury}

One of the primary objectives of the GES study was to identify high- $g$ level crash events by bus damage and onboard injury. Assuming that bus damage classified as "Severe" or requiring towing from the crash scene is the result of a crash that resulted in $>0.75 \mathrm{~g}$ acceleration/ deceleration in the passenger compartment, the GES bus damage data suggest that such events occur approximately one to three times a day in the United States. (Estimated number of transit buses substantially damaged annually $=430-951 ; 430$ buses $/ 365$ days $=1.2$ buses $/$ day; 951 buses/365 days $=2.6$ buses/day.)

However, we can reasonably assume that some of the many moderately damaged buses $(5,285)$ were also involved in crashes that produced elevated $g$ levels (Table 1). Alternatively, not all the buses "Towed due to damage" sustained significant structural damage. For example, minor damage such as broken headlights, which render a bus undriveable after a nighttime crash, may require towing. Confidence in the reported damage severity information is further eroded by the large number of cases coded as "Unknown."

Although the bus damage information from the analysis of GES data is suspect in terms of absolute numbers of severely damaged buses, it does indicate that crashes that produce $>0.75 \mathrm{~g}$ in the passenger compartment are not uncommon. The GES analysis suggests that $~ 5,200$ passengers were exposed to crashes that severely damaged the bus and 11,500 to crashes that rendered the bus undriveable because of some level of damage (430 severely damaged buses $\times 12.1$ passengers/bus $=5,200$; 951 buses towed due to damage $\times 12.1$ passengers/bus $=$ 11,500). Despite the several thousand passengers exposed to crashes that may have produced elevated $g$ levels, we estimate that only 19 passengers annually sustain major injury aboard either damaged or undamaged buses (Table 13).

As in the GES analysis, the motivation for the FARS analysis was to identify and characterize severe crash events, in this case indicated by a fatal injury onboard. In 3 out of 16 (19\%) driver and passenger events, for cases in which collision partner information was reported, the bus hit a roadside structure or tree (Table 2). The Ontario MOT database, which includes a much broader range of bus events, recorded only 57 out of 3,576 events (1.6\%) where the first impact involved a fixed object. This result suggests a higher than average $g$ level for the FARS fatal events.

All but one driver fatality occurred in a crash, and most driver fatalities (63\%) were associated with severely 
Table 14.

Calspan side-impact and bumper test summary. Calspan bus tests were conducted for front bumper and side-impact at 16 and $40 \mathrm{~km} / \mathrm{h}$ car impact speeds, respectively. Bullet car was full-size, U.S. sedan that weighed 1,800 kg.

\begin{tabular}{|c|c|c|c|c|c|}
\hline Test Type & Bus & $\begin{array}{l}\text { Accelerometer } \\
\text { Number }\end{array}$ & $\begin{array}{c}\text { Acceleration } \\
\text { Peak }^{*}\end{array}$ & $\begin{array}{l}\text { Acceleration } \\
10 \text { ms Peak }^{\dagger}\end{array}$ & Comment \\
\hline \multirow[t]{5}{*}{ Side Impact I $^{\ddagger}$} & GM New Look ${ }^{\S}$ & A1 & 12.5 & 7.5 & $\begin{array}{l}5 \mathrm{~cm} \text { deformation. Front wheel of bus } \\
\text { moved laterally } 94 \mathrm{~cm} .\end{array}$ \\
\hline & GMC Transbus $§$ & A1 & - & - & Front wheel of bus moved laterally $25 \mathrm{~cm}$. \\
\hline & Rohr Transbus & A1 & 2.0 & 4.6 & $\begin{array}{l}>18 \mathrm{~cm} \text { deformation. Front wheel of } \\
\text { bus moved laterally } 29 \mathrm{~cm} .\end{array}$ \\
\hline & $\begin{array}{l}\text { AM General } \\
\text { Transbus }\end{array}$ & A1 & 3.0 & 2.0 & $\begin{array}{l}10 \mathrm{~cm} \text { deformation. Front wheel of bus } \\
\text { moved laterally } 13 \mathrm{~cm} .\end{array}$ \\
\hline & Mean & - & 5.8 & 4.7 & - \\
\hline \multirow[t]{5}{*}{ Bumper $^{\dagger \dagger}$} & GM New Look & A2 & 2.2 & 1.6 & $\begin{array}{l}\text { Bumper deformation not recorded. Bus } \\
\text { pushed back } 292 \mathrm{~cm} \text { (measured at } \\
\text { front axle centerline). }\end{array}$ \\
\hline & GMC Transbus & A2 & 1.9 & 1.0 & $\begin{array}{l}\text { Center bumper permanent deformation } \\
2 \mathrm{~cm} \text {. Bus pushed back } 182 \mathrm{~cm} \text {. }\end{array}$ \\
\hline & Rohr Transbus & A2 & 1.6 & 0.9 & $\begin{array}{l}\text { Center bumper permanent deformation } \\
5 \mathrm{~cm} \text {. Bus pushed back } 107 \mathrm{~cm} \text {. }\end{array}$ \\
\hline & $\begin{array}{l}\text { AM General } \\
\text { Transbus }\end{array}$ & A2 & 1.2 & 1.0 & $\begin{array}{l}\text { Bumper deformation not recorded. Bus } \\
\text { pushed back } 152 \mathrm{~cm} \text {. }\end{array}$ \\
\hline & Mean & - & 1.7 & 1.1 & - \\
\hline \multicolumn{6}{|c|}{ 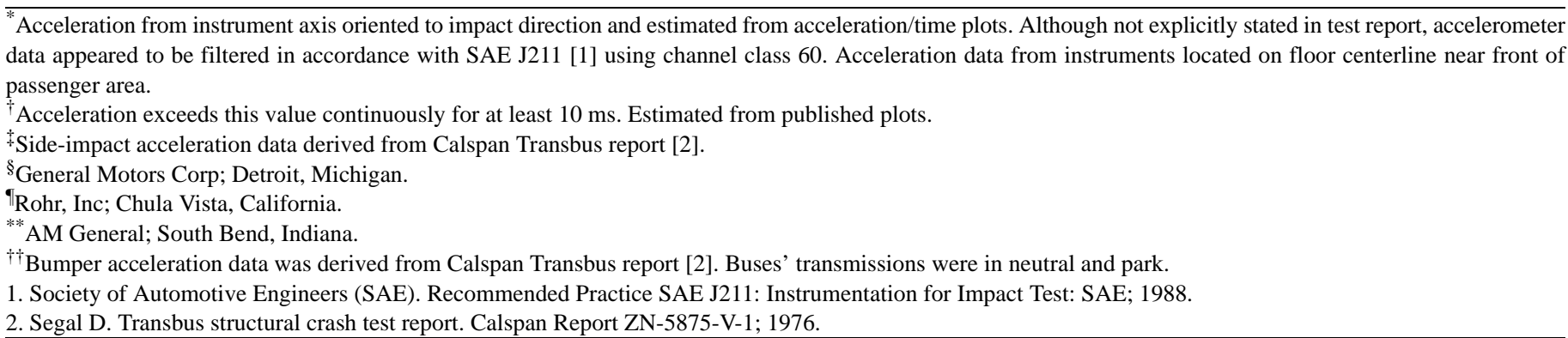 } \\
\hline
\end{tabular}

damaged buses (Table 2). This finding suggests that driver fatality is associated with severe bus damage and, presumably, with elevated $g$-level events. However, the passenger data indicated that a high- $g$ event was not necessary to cause a fatality. While two out of three (67\%) buses sustained severe damage in fatal passenger crashes (similar to the proportion recorded for fatal driver crashes), two of the passenger fatalities aboard a moving bus involved a low- $g$ braking or turning maneuver.

Therefore, an equal number of bus passengers died in high- and low- $g$ events. While this finding suggests that the risk of fatal injury is similar for the severe crashes and vehicle maneuvers for a given time period, it does not suggest that the average individual severe crash is as injurious as the average vehicle maneuver as was erroneously stated in our prior review of German bus data [15]. Table 18 summarizes the German bus data. Although a similar number of Abbreviated Injury Scale 1 (slight) and 3 (serious) [29] injuries were recorded for both event types for the data collection time period, an estimated five times as many occupants aboard the buses were involved in the noncollision events. This finding indicates that occupants aboard the buses involved in crashes with trucks were five times as likely to be injured, evidence that supports the assumption that high- $g$ events are more injurious.

The fact that our study of fatal injuries and the German study both found similar numbers of injuries for low- and high- $g$ events is likely due to the relative frequency of occurrence of the two events. Severe crashes, in which passengers are likely to be injured, happen rarely (we estimate 2-3 a day for all buses in the United States) compared with abrupt vehicle maneuvers, which 
Table 15.

Calspan offset frontal test summary. For offset frontal test, right side of bus was aligned with left (driver) side of impacting car at $90 \mathrm{~km} / \mathrm{h}$ car impact speed. Bullet car was full-size, U.S. sedan that weighed $1,800 \mathrm{~kg}$.

\begin{tabular}{|c|c|c|c|c|c|c|c|}
\hline Bus & $\begin{array}{c}\text { Accelerometer } \\
\text { Number }\end{array}$ & $\begin{array}{l}\text { Accelerometer } \\
\text { Location }^{*}\end{array}$ & $\begin{array}{c}\text { Acceleration } \\
\text { Peak }^{\dagger}\end{array}$ & $\begin{array}{c}\text { Acceleration } \\
5 \text { ms Peak }^{\ddagger}\end{array}$ & $\begin{array}{l}\text { Acceleration } \\
10 \text { ms Peak }^{\ddagger}\end{array}$ & $\begin{array}{c}\text { Max } \\
\text { Permanent } \\
\text { Bumper } \\
\text { Deflection (cm) }\end{array}$ & $\begin{array}{c}\text { Bus Final } \\
\text { Position }^{\S}(\mathbf{c m})\end{array}$ \\
\hline & A4 & Rear floor ${ }^{\dagger \dagger}$ & 7.8 & 6.3 & 3.3 & - & - \\
\hline \multirow[t]{2}{*}{ GMC Transbus } & A2 & Front floor & 13.3 & 5.5 & 3.0 & 15 & 674 \\
\hline & A4 & Rear floor & 5.8 & 5.6 & 5.2 & - & - \\
\hline & A4 & Rear floor & 7.0 & 5.6 & 4.3 & 一 & - \\
\hline \multirow{2}{*}{$\begin{array}{l}\text { AM General } \\
\text { Transbus }^{\S \S}\end{array}$} & A2 & Front floor & 4.9 & 4.0 & 3.8 & 25 & 140 \\
\hline & A4 & Rear floor & 4.5 & 4.5 & 3.8 & - & - \\
\hline \multirow[t]{2}{*}{ Mean } & - & Front floor mean & 12.7 & 7.1 & 3.2 & - & - \\
\hline & - & $\begin{array}{l}\text { Bus final posi- } \\
\text { tion mean }\end{array}$ & - & - & - & - & 298 \\
\hline
\end{tabular}

\footnotetext{
${ }^{*}$ Acceleration data from instruments located on floor centerline.

${ }^{\dagger}$ Acceleration from instrument axis oriented to impact direction and estimated from acceleration/time plots. Although not explicitly stated in test report, accelerometer data appeared to be filtered in accordance with SAE J211 [1] using channel class 60. Acceleration data from instruments located on floor centerline.

${ }^{\ddagger}$ Acceleration exceeds this value continuously for 5 or $10 \mathrm{~ms}$. Estimated from published plots.

§Buses’ transmissions were in neutral and parking brake engaged. Posttest displacement of front axle centerline was reported.

"General Motors Corp; Detroit, Michigan.

${ }^{* *}$ Front floor acceleration data derived from Calspan Transbus report [2].

${ }^{\dagger \dagger}$ Rear floor acceleration data derived from Calspan Transbus report [2].

\#Rohr, Inc; Chula Vista, California.

$\S \S$ AM General; South Bend, Indiana.

1. Society of Automotive Engineers (SAE). Recommended Practice SAE J211: Instrumentation for Impact Test: SAE; 1988.

2. Segal D. Transbus structural crash test report. Calspan Report ZN-5875-V-1; 1976.

Max $=$ maximum
}

may occur several times a day for each of the estimated 44,000 buses in the United States [27].

The regional database reviews failed to find substantial injury in apparently severe crashes. The Ontario MOT database analysis found no relationship between passenger injury severity and bus damage coded as "None,” "Light,” "Moderate,” or “Severe.” In fact, knowing whether a contact was involved did not help to predict injury frequency or severity (Table 5). Moreover, all of the most severe injuries ("Major" injuries) occurred in noncontact events. Preevent bus speed, a parameter that should, on average, rank order crash event $\Delta V$ and $g$ level, was found to have little relationship to injury level (Figure 5).

The Ontario MOT data did, however, suggest a relationship between severe contact events and significant injury for cases in which the bus was described as "Demol- ished," although none of the injuries was coded as major or fatal as the Ontario MOT database recorded no major or fatal injuries in contact events (Figure 3).

Although the request to the NYSDOT database was for "severe transit bus events" and those that "involved bus crashes and resulted in bus occupant injuries and deaths," the NYSDOT staff returned several cases that included no fatalities and no passengers injured severely enough to require hospitalization. This low frequency and severity of injury is similar to that found in the Ontario MOT data review. Even the case that involved a frontal impact with an unyielding concrete staircase failed to produce serious passenger injury (Table 7). In this case, the deceleration apparently exceeded $0.75 \mathrm{~g}$ as evidenced by the unbelted driver being ejected through 

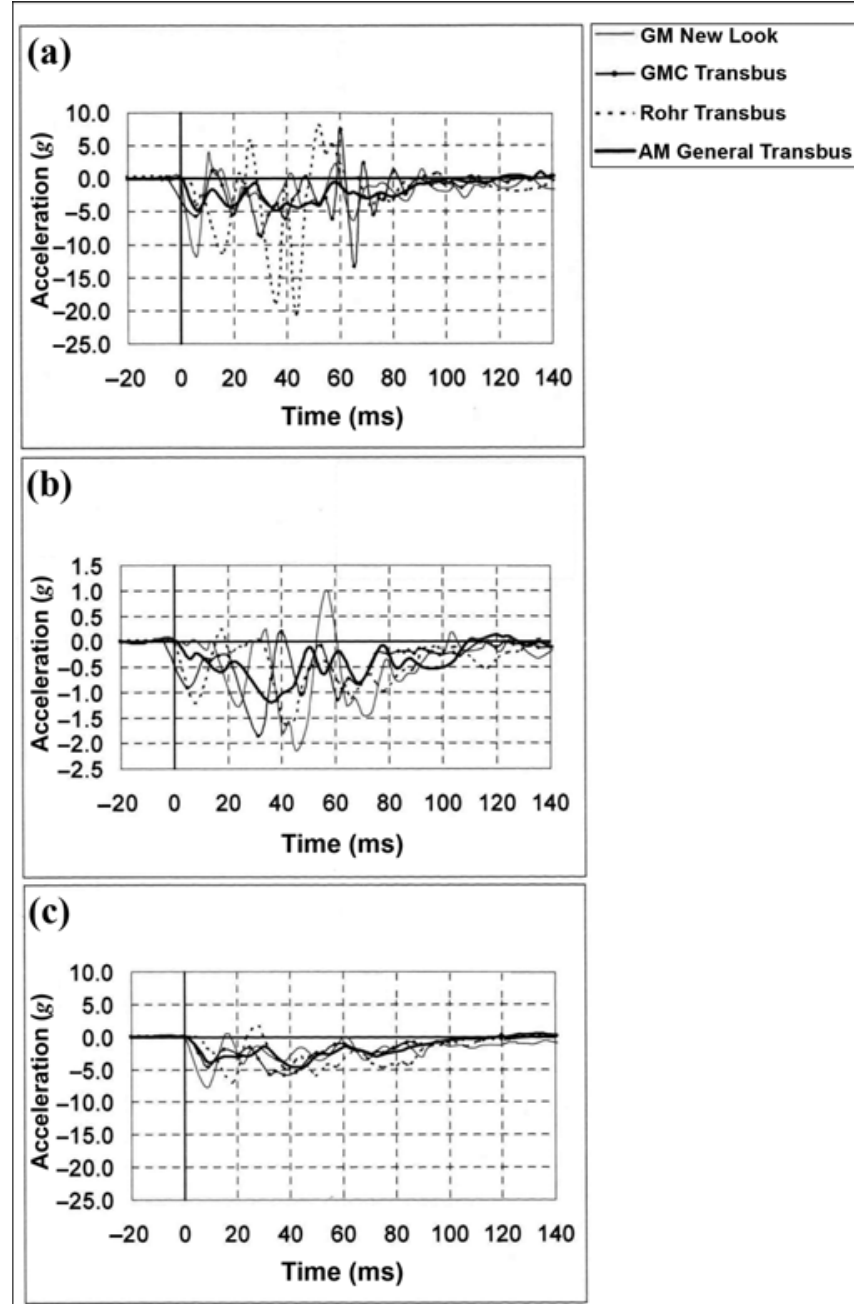

Figure 9.

Acceleration time curves for Calspan tests for (a) offset frontal test, front floor; (b) bumper test; and (c) offset frontal test, rear floor. GM New Look and GMC Transbus: General Motors Corp, Detroit, Michigan; Rohr Transbus: Rohr Inc, Chula Vista, California; AM General Transbus: AM General, South Bend, Indiana. Calspan bus tests were conducted for front bumper, offset frontal impact, and side impact at 16,90 , and $40 \mathrm{~km} / \mathrm{h}$ car impact speeds, respectively. Bullet car was full-size, U.S. sedan that weighed $1,800 \mathrm{~kg}$. Source: Segal D. Transbus structural crash test report. Calspan Report ZN-5875-V-1; 1976.

the windshield, the relatively high precrash bus speed (40-48 km/h), and the reported lack of preimpact braking. Note that of all the cases reviewed, this one was most like laboratory frontal barrier crash tests. However, despite the apparent severity of the crash, none of the passenger injuries required hospitalization.

In summary, with the exception of the $g$-level determination effort, the analyses found a relationship between injury and $g$ level. However, we also found that elevated $g$ levels are not necessary to produce passenger injuries. The FARS, German, and Ontario MOT data indicated that injury levels similar to those in high- $g$ crashes regularly occurred in low- $g$ events. The number of injured and the severity of the injuries were quite low for all the data sources and for all events, even those that produced severe bus damage. This finding is counterintuitive. It is difficult to understand how unrestrained and often standing bus riders, whose ranks include many frail older adults, are not more frequently and more severely injured in events that result in a severely damaged bus and/or in which the peak $g$ level exceeds $13 \mathrm{~g}$. Possible explanations include the following:

1. Database bus damage information, primarily provided by police reports, is not a reliable indicator of onboard $g$ level.

2. Bus construction may limit the $g$ level felt in the passenger compartment despite the appearance of substantial damage to the bus exterior.

3. Bus interior components, such as seat backs, may be effective at limiting peak forces on passengers who are thrown into them in a high- $g$ event.

4. The $g$-level determination effort that relied on very limited crash reconstruction information overestimated $g$ levels. Moreover, the estimates relied on a limited number of crash tests of 30-year-old transit bus designs. Three of the buses tested by Calspan were nonproduction prototypes and none were low floor buses, an increasingly common type in current use. Performance of modern configuration and construction buses on the Calspan tests is unknown.

5. The effect of $g$ level on bus passengers may not be adequately expressed by the peak acceleration/deceleration alone. For example, both the $g$ level and the duration of the acceleration/deceleration or "crash pulse" were specified for the dynamic test of WTORS [30]. Further investigation is required to determine critical combinations of $g$ level and duration for passengers who sit on the vehicle seat and those who sit in wheelchairs.

\section{Wheelchair Rider Safety}

Although the study primarily examined events injurious to the general ridership in order to estimate the transit environment for the wheelchair rider, we did evaluate a limited number of events that involved a wheelchair rider. The FARS analysis identified a single wheelchair rider fatality aboard a transit bus in a noncrash event. The WSTIP database provided valuable information on 
Table 16.

University of Michigan Transportation Research Institute (UMTRI) database: Transit bus peak acceleration estimates.

\begin{tabular}{|c|c|c|c|c|c|c|c|c|}
\hline $\begin{array}{l}\text { UMTRI } \\
\text { Case No. }\end{array}$ & $\begin{array}{c}\text { Relative } \\
\text { Velocity }^{*} \\
(\mathbf{k m} / \mathbf{h})\end{array}$ & $\begin{array}{c}\text { Bus } \Delta V^{*} \\
(\mathbf{k m} / \mathbf{h})\end{array}$ & $\begin{array}{l}\text { Bus Mass }^{\dagger} \\
\text { (kg) }\end{array}$ & $\begin{array}{l}\text { Car Mass }{ }^{\ddagger} \\
(\mathbf{k g})\end{array}$ & Crash Type & Summary & \begin{tabular}{c}
\multicolumn{1}{c}{ Peak } \\
Acceleration \\
Estimate $(g)$
\end{tabular} & Comment \\
\hline 414 & 42 & 3 & 13,866 & 1,225 & Frontal & $\begin{array}{l}\text { Bus hit side of } \\
\text { car }\end{array}$ & $<13$ & $\begin{array}{l}\text { Much less energy than } \\
\text { Calspan offset frontal. }{ }^{q} \text { If } \\
\text { bus } \Delta V \text { is correct, peak } \\
<1.7 \mathrm{~g} \text {. }\end{array}$ \\
\hline 418 & 140 & 12 & 13,558 & 1,270 & Frontal & $\begin{array}{l}\text { Bus hit side of } \\
\text { car }\end{array}$ & $>13$ & $\begin{array}{l}\text { More energy than Calspan } \\
\text { offset frontal. }\end{array}$ \\
\hline 419 & 35 & 2 & 14,297 & 1,016 & Frontal & $\begin{array}{l}\text { Bus hit side of } \\
\text { car }\end{array}$ & $<1.7$ & $\begin{array}{l}\text { Much less energy than } \\
\text { Calspan offset frontal \& } \\
<1.7 \mathrm{~g} \text { Calspan bumper test } \\
(1,800 \mathrm{~kg} \text { car at } 16 \mathrm{~km} / \mathrm{h}) \text {. }\end{array}$ \\
\hline 422 & 42 & 5 & 13,041 & 1,665 & Frontal & $\begin{array}{l}\text { Bus hit side of } \\
\text { car }\end{array}$ & $<13$ & $\begin{array}{l}\text { Less energy than Calspan } \\
\text { offset frontal. }\end{array}$ \\
\hline 425 & 193 & 94 & 13,585 & 1,277 & Frontal & $\begin{array}{l}\text { Bus hit car } \\
\text { head-on }\end{array}$ & $>13$ & $\begin{array}{l}\text { Much more energy than } \\
\text { Calspan offset frontal. }\end{array}$ \\
\hline 428 & 68 & 9 & 13,608 & 2,041 & Side & $\begin{array}{l}\text { Car hit side of } \\
\text { bus }\end{array}$ & $>5.8$ & $\begin{array}{l}\text { More energy than Calspan } \\
\text { side-impact test; }{ }^{\S} \text { higher } \\
\text { speed ( } 42 \text { vs } 25 \mathrm{mph}) \& \\
\text { slightly higher car mass } \\
\text { (2,050 vs } 1,800 \mathrm{~kg} \text { ). }\end{array}$ \\
\hline
\end{tabular}

wheelchair riders, although the cases occurred aboard paratransit vans and not transit buses. The four WSTIP wheelchair rider cases did not involve a crash, yet were disproportionately frequent and costly compared with claims involving the general ridership. If claim costs are an indication of injury severity, as suggested by WSTIP staff, then wheelchair riders appear to be more vulnerable to injury than other riders, a reasonable possibility given that many are physically frail and that WTORS are often insufficient.

Similar findings of disproportionate problem frequency for wheelchair riders have been reported. The 1986 Urban Mass Transit Administration (now the Federal Transit Administration) workshop proceedings reported that the Southern California Rapid Transit District "has documented that wheelchair patrons have an accident rate 
Table 17.

University of Michigan Transportation Research Institute database: Transit bus peak acceleration estimates versus injuries.

\begin{tabular}{|c|c|c|c|c|c|c|c|}
\hline \multirow{2}{*}{$\begin{array}{c}\text { Peak } \\
\text { Acceleration } \\
\text { Estimate }(g)\end{array}$} & \multirow{2}{*}{$\begin{array}{c}\text { No. } \\
\text { Occupants } \\
\text { Onboard }^{*}\end{array}$} & \multicolumn{6}{|c|}{ Injury $^{\dagger}$} \\
\hline & & All & Possible & $\begin{array}{c}\text { Evident But } \\
\text { Nonincapacitating }\end{array}$ & Incapacitating & Fatal & Unknown \\
\hline$<13$ & Unknown & 1 & 0 & 1 & 0 & 0 & 0 \\
\hline$<13$ & 4 & 4 & 4 & 0 & 0 & 0 & 0 \\
\hline$<13$ & Unknown & 4 & 4 & 0 & 0 & 0 & 0 \\
\hline$>13$ & 4 & 4 & 4 & 0 & 0 & 0 & 0 \\
\hline$>13$ & 5 & 5 & 5 & 0 & 0 & 0 & 0 \\
\hline$>13$ & 2 & 1 & 0 & 1 & 0 & 0 & 0 \\
\hline$>13$ & 5 & 1 & 1 & 0 & 0 & 0 & 3 \\
\hline$<1.7$ & 2 & 1 & 1 & 0 & 0 & 0 & 0 \\
\hline$>5.8$ & 4 & 4 & 0 & 3 & 1 & 0 & 0 \\
\hline Total & - & 25 & 19 & 5 & - & - & - \\
\hline \multicolumn{8}{|c|}{$\begin{array}{l}{ }^{*} \text { Includes driver. } \\
{ }^{\dagger} \text { Assumes } 1 \text { injury (most severe) per occupant. Coding scale was developed for nonmedical personnel and provides only relative injury severity. Information does } \\
\text { not indicate whether injury required hospitalization. Injury designations presented here are those in General Estimates System database and are also used by various } \\
\text { states. Possible = not visible, complaint of pain, probable-not apparent, shock; Evident But Nonincapacitating = minor injury, moderate injury, minor visible injury, } \\
\text { bruise/abrasion/swelling, nonsevere visible injury, minor burn or bleed, shock, refused medical treatment; Incapacitating = severe injury, serious visible injury, } \\
\text { major injury, moderate injury, visible injury or carried from scene, evident-incapacitating, disabled, semiconscious, incoherent, unconscious, severed limb, internal } \\
\text { injury, minor or severe burn or bleed, fracture/dislocation, concussion, shock. }\end{array}$} \\
\hline
\end{tabular}

Table 18.

German motor insurers bus incidents. Buses with capacity $>25$ involved in events resulting in 1 minor (Abbreviated Injury Scale [AIS] 1 [1]) injury from 1978 to 1985 . (Data collection end date not specified [2].)

\begin{tabular}{lcc}
\hline \multicolumn{1}{c}{ Number } & Noncollision & $\begin{array}{c}\text { Bus/Truck } \\
\text { Collision }\end{array}$ \\
\hline Buses/Events & 142 & 18 \\
Occupants & $1,718^{*}$ & 328 \\
AIS 1 or Slight & 58 & 62 \\
$\quad$ Injuries & & 10 \\
AIS 3 or Serious & 8 & \\
$\quad$ Injuries & &
\end{tabular}

${ }^{*}$ Number of occupants estimated for noncollision events with assumed average of 12.1 passengers per bus [2].

1. Association for the Advancement of Automotive Medicine (AAAM). The abbreviated injury scale—1990 revision. Update 98. Des Plaines (IL): AAAM; 1998.

2. Langwieder K, Danner M, Hummel T. Collision types and characteristics of bus accidents-Their consequences for bus passengers and the accident opponent. In: Proceedings of the 10th International Conference on Experimental Safety Vehicles; 1985; London, England. Washington (DC): National Highway Transportation Safety Administration; 1985. p. 585-913.

of over 350 times greater than ambulatory passengers" [9]. A more recent study reported that wheelchair riders account for 3 to 10 percent of passenger incidents [27], while comprising only 0.24 percent of the general ridership (WSTIP analysis).

While this study and others provide evidence to support the conclusion that wheelchair riders are more likely to be injured than the general ridership, other factors should be considered. In this study, all of the reviewed wheelchair rider events occurred on paratransit buses, whose vehicle maneuvers may be more frequent and/or pronounced than those of the large transit bus. (Alternately, this finding may reflect greater use of such vehicles by wheelchair riders [10].) Reports and claims regarding wheelchair riders may be more frequent given concerns of liability.

\section{Information Necessary to Improve Wheelchair Rider Safety: Transit Bus Events Characterization}

The objective of this study was to fully characterize injury-producing transit bus events in order to provide the information necessary for establishing an appropriate level of crash protection for wheelchair riders. The study sought to determine the frequency, severity, and principal impact direction of these events. Although some progress was made toward these goals, the study's overall objective was not fully realized. The most ambitious goal, determining the range of $g$-level events and their frequency of occurrence, proved to be largely out of reach. However, the study did provide a better understanding of transit bus events.

\section{Low-g Events}

Low- $g$ events (peak acceleration/deceleration $<0.75 \mathrm{~g}$ ), such as those involving abrupt braking, apparently occur 
frequently given that they account for half of onboard passenger injuries and, in this study, for all of the wheelchair riders' injuries as well as the only onboard fatality identified by the FARS analysis. This finding was similar to that of a study of a large urban transit system that indicated all the wheelchair rider incidents were caused by vehicle maneuvers and that many onboard bus fatalities for the general ridership were caused by noncollision events [10].

\section{High-g Events}

High- $g$ events (peak acceleration/deceleration $>0.75 g$ ) associated with crashes occur roughly 500 to 1,000 times a year in the United States. This very approximate estimate was based on the assumption that bus crash damage could be used to sort events as either low or high $g$. However, this approach did not allow an estimate of the $g$ levels for the high- $g$ events. The limited $g$-level determination effort suggested that the high- $g$ events could be subdivided into those in which the peak $g$ level was $<13 \mathrm{~g}$ or $>13 g$ but did not provide information regarding event frequency. Greater specificity in terms of $g$-level ranges and associated event frequencies were the study objectives.

The study was more successful in determining the direction of impact for transit bus crashes. All the data sources that recorded direction of impact indicated that most of the injurious events involved the bus rapidly decelerating because of frontal impacts with another vehicle or roadside object. This finding, based on Ontario MOT data, was also reported by most prior studies and suggests that the common practice of designing WTORS primarily for frontal impacts is applicable for transit buses [22]. One study, conducted by the Emergency Care Research Institute, did not find sufficient evidence to select any one impact direction for transit buses [10]. In addition, we found that most noncollision events involved braking or turning.

\section{Implications for WTORS Performance Criteria}

The finding that many injuries occur during low- $g$ events suggests that occupant protection systems designed for such events would significantly reduce injury. The Ontario MOT database analysis suggests that eliminating injury in noncontact events would reduce overall injury frequency by 50 percent. Given the results of this study and others, protection for both braking and turning is a higher priority than for accelerating.

While we found ample evidence that wheelchair rider protection for low- $g$ events is justifiable, sufficient evi- dence to formulate recommendations regarding high- $g$ crash events was quite limited. The data did suggest a priority for protection in frontal impacts. The results of this study are inadequate for evaluating the existing ADA WTORS requirements predicated on the 8 to $10 \mathrm{~g}$ peak deceleration level.

\section{Study Limitations and Recommendations for Further Investigation}

Because of a scarcity of information regarding wheelchair rider injuries, this study attempted to infer injury risk for this population by examining the somewhat more available data regarding injuries to transit bus general ridership. However, good information for the general ridership was limited, which resulted in compromises in the study design. Instead of sampling U.S. transit providers based on geographic region and traffic density/speeds, we selected information sources from both the United States and Canada based on the quality of the databases and the access allowed us. The $g$-level determination effort relied on very limited crash reconstruction information and on data from a limited number of crash tests with older transit buses. Moreover, the effect of $g$ level on bus passengers and wheelchairs was not investigated. Further work is needed to establish parameters, such as duration above a certain acceleration level, that adequately characterize the crash environment and to identify events that are potentially injurious. Subsequent investigation of bus crashes is needed to determine the frequency of these elevated $g$-level events and the crash pulse effects on wheelchair riders, their wheelchairs, and WTORS.

The most challenging task would be gathering event crash pulses. Fortunately, the U. S. National Transportation Safety Board (NTSB) via its 2001 "NTSB Most Wanted List of Transportation Safety Improvements," has recommended that transit providers install event data recorders in their transit bus fleets that are capable of recording crash pulses [31]. Having this data would greatly assist in crash-reconstruction efforts. Computer models, developed and verified with laboratory sled tests, could be used to estimate the behavior of a wheelchair and rider in response to a wide range of recorded crash pulses.

Ultimately, this effort would inform the development of transit bus crash pulse corridors, the first of which that reflect a frontal impact. Crash pulse corridors developed with this approach could define the conditions of a test 
that assesses transit bus WTORS as has been done for general use WTORS [30].

The advantage of this proposed approach would be that WTORS designed for use on transit buses could be evaluated by a test developed from real-world crash data and would provide a level of protection commensurate with real-world risk. This approach would encourage the development of WTORS tailored to transit buses that appropriately balance crash protection with factors such as cost and ease of use. We anticipate that this effort would recommend a lower severity crash pulse than the one for which the current four-strap tie-down system is designed and may allow more user-friendly systems, such as the rear-facing wheelchair compartment concept, a configuration that is reported to provide protection during a $3 \mathrm{~g} / 10 \mathrm{~ms}$ duration crash pulse [23].

\section{CONCLUSIONS}

The data reviewed during the course of this study supported the finding of prior research that the large transit bus is a very safe form of transportation. Examination of the relatively few collision and noncollision injuryproducing transit bus events provided useful, if incomplete, information that enabled characterization of the events in terms of passenger compartment $g$ level and direction of acceleration/deceleration. This information is required to develop WTORS tailored to the transit bus environment and is summarized as follows:

1. Low- $g$ events, such as those involving abrupt braking or turning, occur frequently and account for half of onboard passenger injuries and, in this study, account for all of the wheelchair riders' fatal and nonfatal injuries. This result implies that WTORS that sacrifice high- $g$ protection for improved ease of use could reduce injury risk significantly.

2. Bus damage reports suggest that high- $g$ crash events occur roughly 500 to 1,000 times a year in the United States.

3. Some bus crashes involve passenger compartment peak $g$ levels $>13 g$. The frequency of these and other high- $g$ events was not determined. Therefore, the results of this study are inadequate for suggesting a reasonable peak $g$ level for protection.

4. All the data sources that recorded direction of impact indicated that most of the injurious events involved the bus rapidly decelerating because of frontal impacts with another vehicle or roadside object. This finding was also reported by most prior studies and suggests that transit bus WTORS should be designed with protection during frontal crashes as a priority.

5. The data suggest that wheelchair rider protection for low- $g$ events is justifiable, while sufficient evidence to formulate recommendations regarding high- $g$ crash events is limited.

Further study is needed to determine the magnitude of elevated $g$-level events and how frequently they occur. The effects of a range of real-world crash pulses on wheelchairs and their riders should be investigated. This information is needed to determine a level of protection commensurate with real-world risk for wheelchair riders on large transit buses.

\section{ACKNOWLEDGMENTS}

Many thanks to Larry Schneider, UMTRI, who provided valuable information and critique for this article; Dan Blower, UMTRI, who participated in the $g$-level event analysis and helped with FARS coding; Charles Compton, who assisted with UMTRI GES coding; Yossary Elzohairy, Ontario MOT, who provided both data and generous technical assistance; John Fabian, who provided case studies from the NYSDOT; and Al Hatten, who provided a spreadsheet of data from the WSTIP.

This material is the result of work supported with resources of the U.S. Department of Education, National Institute of Disability and Rehabilitation Research through the Rehabilitation Engineering Research Center on Wheelchair Transportation Safety located at the University of Pittsburgh.

The author has declared that no competing interests exist.

\section{REFERENCES}

1. Schneider L, chair. Proceedings of the ANSI/RESNA Subcommittee on Wheelchairs and Transportation. 1999 Jun 25-26; Long Beach, CA. Arlington (VA): RESNA Press;1999.

2. Hobson DA. Wheelchair transport safety-The evolving solutions. J Rehabil Res Dev. 2000;37(5):vii-XV.

[PMID: 11322162]

3. Ketola HN, Chia D. Assessment of Americans with Disabilities Act research and development needs. Final report. Washington (DC): U.S. Department of Transportation; 1997. 
4. U.S. Architectural and Transportation Barriers Compliance Board. Buses, vans and systems: Technical assistance manual. Washington (DC): U.S. Department of Transportation, U.S. Architectural and Transportation Barriers Compliance Board; 1992.

5. Rutenberg U, Hemily PB. Use of rear-facing position for common wheelchairs on transit buses. Washington (DC): Transportation Research Board; 2003.

6. Rutenberg U. Urban transit bus accessibility considerations. Toronto (Canada): Canadian Urban Transit Association; 1995.

7. Khadilkar A, Will E, Costa V. Crash protection systems for handicapped school bus occupants. Vol. I. Executive summary. Final report. Report No.: DOT-HS-805-826. Washington (DC): U.S. Department of Transportation, National Highway Traffic Safety Administration; 1981.

8. Stewart CF, Reinl HG. Wheelchair securement on bus and paratransit vehicles. Washington (DC): United States Urban Mass Transportation Administration; 1981.

9. Battelle Memorial Institute. National workshop on buswheelchair accessibility: Guideline specifications for wheelchair securement devices. Washington (DC): U.S. Department of Transportation, Urban Mass Transportation Administration; 1986.

10. Easter Seals Project ACTION, ECRI. Positioning and securing riders with disabilities and their mobility aids in transit vehicles: Designing an evaluation program. Final report. Washington (DC): Easter Seals Project ACTION; 1997.

11. Booz, Allen and Hamilton, Inc. Transbus safety and human factors. Summary Report (1971-1976) No. TR 77-004 prepared for the U.S. Department of Transportation under contract No. DOT-UT-10008 by Booz, Hamilton and Allen, Inc. Bethesda: (MD); September 1977.

12. Le Claire M. The safety of wheelchair occupants in road passenger vehicles. London (England): Transport Research Laboratory; 2003.

13. Petty SP. The safe transportation of wheelchair occupants in the United Kingdom. In: Proceedings of the 10th International Technical Conference on Experimental Safety Vehicles; 1985: London, England. Washington (DC): National Highway Transportation Safety Administration; 1985. p. 488-91.

14. Shaw G. Wheelchair rider risk in motor vehicles: A technical note. J Rehabil Res Dev. 2000;37(1):89-100. [PMID: 10847576]

15. Shaw G, Gillispie T. Appropriate protection for wheelchair riders on public transit buses. J Rehabil Res Dev. 2003; 40(4):309-19. [PMID: 15074442]

16. Kirby R, MacLeod D. Wheelchair-related injuries reported to the national electronic injury surveillance system: an update. In: Proceedings of the Rehabilitation Engineering and Assistive Technology Society of North America
(RESNA) Annual Conference; 2001 Jun 22-26. Arlington (VA): RESNA; 2001. p. 385-87.

17. National Highway Traffic Safety Administration. The National Automotive Sampling System General Estimates System analytical user's manual 1988-1999. Washington (DC): U.S. Department of Transportation, National Highway Traffic Safety Administration, National Center for Statistics and Analysis; 2000.

18. U.S. Department of Transportation. Traffic safety facts 2001. Washington (DC): U.S. Department of Transportation, National Highway Traffic Safety Administration; 2002.

19. Shanley JW. Safety in mass transit: A case study of bus accidents in Washington, DC. Washington (DC): Consortium's Urban Transportation Center; 1974.

20. National Safety Council. Injury facts, 2002 edition. Itasca (IL): National Safety Council; 2002.

21. Blower D, Schneider L, Woodrooffe J. Characterization of transit-bus accidents resulting in passenger injuries for use in developing alternative methods for transporting wheelchair-seated travelers. In: Proceedings of International Truck \& Bus Safety \& Security Symposium; 2005 Nov 1416. Itasca (IL): National Safety Council; 2005.

22. Segal D. Transbus structural crash test report. Calspan Report ZN-5875-V-1; 1976.

23. Rutenberg U, Baerg R, MacNabb M, Little A, Hemily B. Assessment of low floor transit bus $\mathrm{g}$ forces on rear-facing wheelchair securement systems. Report Number TP 14429E. Montreal Transportation and Development Centre. Ottawa, Ontario (Canada): Transport Canada; 2005.

24. Langwieder K, Danner M, Hummel T. Collision types and characteristics of bus accidents-Their consequences for bus passengers and the accident opponent. In: Proceedings of the 10th International Technical Conference on Experimental Safety Vehicles; 1985; London, England. Washington (DC): National Highway Transportation Safety Administration; 1985. p. 585-913.

25. Lawrence GJ. Study of improved safety for minibuses by better seat and occupant retention. United Kingdom: Transport Research Laboratory; 2000.

26. Transportation Resource Associates, Inc. Transit bus safety program: Task 2-Regulations and oversight (Federal, state, local \& industry). Final Report. Washington (DC): U.S. Department of Transportation, Federal Transit Administration; 2001.

27. King R. Bus occupant safety. Project SF-1: TCRP Synthesis of transit practice, Issue 18. Transportation Research Board, National Research Council. Washington (DC): National Academies Press; 1996.

28. Gearhart C. Recent progress in crash pulse analysis. Int J Vehicle Des. 2001;26(4):395-406. 
29. Association for the Advancement of Automotive Medicine (AAAM). The abbreviated injury scale-1990 revision. Update 98. Des Plaines (IL): AAAM; 1998.

30. Society of Automotive Engineers (SAE). Recommended Practice SAE J2249: Wheelchair tie-downs and occupant restraint systems for use in motor vehicles: SAE; 1997.

31. Kowalick TM. Pros and cons of emerging event data recorders (EDRs) in the highway mode of transportation. In: Pro- ceedings of the 53rd IEEE Vehicular Technology Conference, Volume 4; 2001 May 6-9; Rhodes, Greece. New York: IEEE; 2001. p. 3037-41.

Submitted for publication March 19, 2007. Accepted in revised form July 17, 2007. 